\title{
Cellular Composition and Three-Dimensional Organization of the Subventricular Germinal Zone in the Adult Mammalian Brain
}

\author{
Fiona Doetsch, ${ }^{1}$ Jose Manuel García-Verdugo, ${ }^{2}$ and Arturo Alvarez-Buylla ${ }^{1}$ \\ ${ }_{1}^{1}$ The Rockefeller University, New York, New York 10021, and 2Universidad de Valencia, Burjasot-46100, Valencia, Spain
}

The adult mammalian subventricular zone (SVZ) contains stem cells that give rise to neurons and glia. In vivo, SVZ progeny migrate $3-8 \mathrm{~mm}$ to the olfactory bulb, where they form neurons. We show here that the SVZ of the lateral wall of the lateral ventricles in adult mice is composed of neuroblasts, glial cells, and a novel putative precursor cell. The topographical organization of these cells suggests how neurogenesis and migration are integrated in this region. Type $A$ cells had the ultrastructure of migrating neuronal precursors. These cells were arranged as chains parallel to the walls of the ventricle and were polysialylated neural adhesion cell molecule- (PSA-NCAM), TuJ1- ( $\beta$-tubulin), and nestinpositive but GFAP- and vimentin-negative. Chains of Type $A$ cells were ensheathed by two ultrastructurally distinct astrocytes (Type B1 and B2) that were GFAP-, vimentin-, and nestin-positive but PSA-NCAM- and TuJ1-negative. Type A and B2 (but not B1) cells incorporated $\left[{ }^{3} \mathrm{H}\right]$ thymidine. The most actively dividing cell in the SVZ corresponded to Type $C$ cells, which had immature ultrastructural characteristics and were nestin-positive but negative to the other markers. Type $C$ cells formed focal clusters closely associated with chains of Type A cells. Whereas Type $C$ cells were present throughout the SVZ, they were not found in the rostral migratory stream that links the SVZ with the olfactory bulb. These results suggest that chains of migrating neuroblasts in the SVZ may be derived from Type C cells. Our results provide a topographical model for the adult SVZ and should serve as a basis for the in vivo identification of stem cells in the adult mammalian brain.

Key words: subventricular zone; subependymal zone; neurogenesis; stem cells; ultrastructure; tangential migration; chain migration; astrocytes; ependyma
The subventricular zone (SVZ) is an important germinal layer that forms during development adjacent to the telencephalic ventricular zone. This layer is most prominent in the lateral wall of the lateral ventricle facing the developing ganglionic eminences. Interestingly, the SVZ persists into adulthood (Allen, 1912; Smart, 1961; Altman, 1969; Sturrock and Smart, 1980), where it retains the capacity to generate both neurons and glia (Lois and Alvarez-Buylla, 1993; Kirschenbaum and Goldman, 1995). In neonatal (Luskin, 1993) and adult mice (Lois and Alvarez-Buylla, 1994), cells born in the SVZ migrate along a restricted pathway, called the rostral migratory stream (RMS) (Altman, 1969), to the olfactory bulb, where they differentiate into granule and periglomerular neurons. These cells migrate as elongated aggregates of cells called chains (Rousselot et al., 1995; Lois et al., 1996) without the aid of radial glia or axonal guides. More recently, we have shown that not only the RMS but the entire SVZ contains chains, which form an extensive network that extends from the caudal to the rostral lateral wall of the lateral ventricle. Transplantation and microlabeling experiments indicate that cells arising at different rostrocaudal levels of this network migrate rostrally and join the RMS to reach the olfactory bulb (Doetsch and Alvarez-Buylla, 1996). The extensive tangential

Received Dec. 23, 1996; revised March 19, 1997; accepted April 15, 1997.

F.D. is a Baker Fellow. This work was supported by National Institutes of Health: National Institute of Child Health and Human Development Grant NICHD NS32116 and National Institute of Neurological Disorders and Stroke Grant NINDS-NS28478. We thank Drs. A. Frankfurter, G. Rougon, U. Lendahl, and R McKay for their kind gifts of antibodies. We thank E. Font, C. Lois, and C. Scharff for helpful comments on this manuscript.

F.D. and J.M.G.-V. contributed equally to this work.

Correspondence should be addressed to Dr. Arturo Alvarez-Buylla, The Rockefeller University, 1230 York Avenue, New York, NY 10021.

Copyright (C) 1997 Society for Neuroscience 0270-6474/97/175046-16\$05.00/0 migration of neuronal precursors through the SVZ of adult mammals suggests that progenitors for adult neurogenesis are distributed throughout this wall. The three-dimensional topographical organization of the SVZ and the cells that give rise to the migrating neuronal precursors have not been identified.

The postnatal SVZ is also a site of gliogenesis (Paterson et al., 1973; Levison and Goldman, 1993), and in vitro experiments indicate that multipotent neuronal stem cells reside in this germinal layer (for review, see Alvarez-Buylla and Lois, 1995; Calof, 1995; Gage et al., 1995b; Weiss et al., 1996b). SVZ grown with EGF or bFGF retain the capacity for self-renewal and can generate both neurons and glia (Reynolds and Weiss, 1992; Gritti et al., 1996; Johe et al., 1996). The presence of neuronal stem cells in this adult mammalian germinal zone raises the possibility of using the SVZ as a source of precursors for transplantation and neuronal replacement after injury or disease.

Earlier studies describe the SVZ as a collection of darkly and lightly stained cells of undifferentiated morphology, glial cells, and cells with transitional morphologies. It has been suggested that the dark and light cells represent different stages in the production of glial cells (Smart, 1961; Blakemore, 1969; Privat and Leblond, 1972 ) or that they correspond to separate glioblast lineages (Sturrock and Smart, 1980). However, these studies did not take into account that the SVZ contains multipotent stem cells and that it is the site of neurogenesis and of extensive tangential neuronal migration.

In the present study we established ultrastructural and immunocytochemical criteria for the identification of cell types in the adult rodent SVZ. Three main cell types were identified: (1) neuroblasts or Type A cells, which correspond to the previously described dark cells; (2) astrocytes (Type B1 and B2 cells), which 
Table 1. Morphological characteristics of different cell types in the adult mouse SVZ

\begin{tabular}{|c|c|c|c|c|c|c|}
\hline & $\begin{array}{c}\text { A } \\
\text { migrating neuroblast }\end{array}$ & $\begin{array}{c}\text { B1 } \\
\text { astrocyte }\end{array}$ & $\begin{array}{c}\mathrm{B} 2 \\
\text { astrocyte }\end{array}$ & $\begin{array}{c}\text { C } \\
\text { putative precursor }\end{array}$ & $\begin{array}{c}\text { D } \\
\text { tanycytes } \\
\end{array}$ & $\begin{array}{c}E \\
\text { ependymal } \\
\end{array}$ \\
\hline SIZE ( $(\mu \mathrm{m} 2)$ & $31 \quad(8.4)$ & $58(16.1)$ & $43(10.4)$ & $62(18.9)$ & n.d. & $117(28.1)$ \\
\hline CONTOUR & elongated, smooth & irregular & irregular & smooth and elliptical & lateral extensions & interdigitating \\
\hline CYTOPLASM & dark, scant & light (lighter than B2) & light (darker than B1) & int. between $A$ and $B$ & dark & very light \\
\hline NUCLEI & $\begin{array}{l}\text { elongated, } \\
\text { occas. invag }\end{array}$ & $\begin{array}{l}\text { irregular, } \\
\text { freq. invaginated }\end{array}$ & $\begin{array}{l}\text { irregular, } \\
\text { freq. invaginated }\end{array}$ & $\begin{array}{l}\text { large spherical-irreg., } \\
\text { deep invaginations }\end{array}$ & $\begin{array}{l}\text { irrregular, } \\
\text { invaginated }\end{array}$ & $\begin{array}{l}\text { spherical, } \\
\text { no invag }\end{array}$ \\
\hline CHROMATIN & lax & non-clumped & clumped & mostly lax, some clumps & dark aggregates & non-clumped \\
\hline NUCLEOLI & 2 to 4 & 1 to 2 & 1 to 2 & reticulated & 1 to 2 & 1 to 2 \\
\hline $\mathrm{PER}$ & + & ++ & ++ & $+t+$ & +++ & + \\
\hline GOLGI & small & medium & medium & large & large & small \\
\hline MITOCHONDRIA & + & +++ & ++ & +++ & ++++ & +++ \\
\hline FREERIBOSOMES & ++++ & + & ++ & +++ & ++ & + \\
\hline INTER. FILAMENTS & no & yes & yes & no & yes & yes \\
\hline MICROTUBULES & ++++ & + & + & ++ & + & + \\
\hline LIPID DROPLETS & no & no & no & no & no & yes \\
\hline DENSE BODIES & no & yes & yes & no & no & yes \\
\hline CILIA, MICROVILLI & no & no & no & no & microvilli & both \\
\hline CONTACTS & $A-A ; A-C$ & B-B; B-E & B-B; B-E & $\mathrm{C}-\mathrm{C} ; \mathrm{C}-\mathrm{A}$ & D-E; D-B & E-E; E-B \\
\hline
\end{tabular}

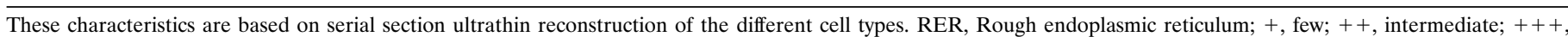
abundant; ++++ , extremely abundant. SD in parentheses; n.d., not determined.

correspond to the previously described light cells; and (3) an undifferentiated cell, Type $\mathrm{C}$ cells, which may correspond to putative precursors. Serial section reconstructions revealed that Type A cells formed tangentially oriented chains ensheathed by Type B1 and B2 cells and that clusters of proliferating Type C cells were focally associated with the chains of neuroblasts. On the basis of this organization we propose a model integrating neurogenesis and tangential migration in the SVZ.

\section{MATERIALS AND METHODS}

Adult male and female mice were anesthetized deeply with Nembutal and perfused transcardially with $0.9 \%$ saline, followed by either $100 \mathrm{ml}$ of Karnovsky's fixative (2\% paraformaldehyde and $2.5 \%$ glutaraldehyde) for conventional electron microscopy or by $100 \mathrm{ml}$ of $4 \%$ paraformaldehyde and $0.1 \%$ glutaraldehyde for immunocytochemistry. The heads were removed and post-fixed in the same fixative overnight. Then the brains were removed from the skull and washed in $0.1 \mathrm{M}$ phosphate buffer $(\mathrm{PB})$ for $2 \mathrm{hr}$.

Electron microscopy. Transverse or sagittal $100 \mu \mathrm{m}$ sections were cut on a vibratome. The sections were post-fixed in $2 \%$ osmium for $2 \mathrm{hr}$, rinsed, dehydrated, and embedded in Araldite (Durcupan, Fluka BioChemika, Ronkonkoma, NY). To study the overall organization of the SVZ, we cut serial $1.5 \mu \mathrm{m}$ semithin sections with a glass knife and stained them with $1 \%$ toluidine blue. For the identification of individual cell types, ultrathin $(0.05 \mu \mathrm{m})$ sections were cut with a diamond knife, stained with lead citrate, and examined under a Jeol 100CX electron microscope. The transverse semi- and ultrathin sections studied encompassed the entire dorsoventral extent of the SVZ of the lateral ventricle. To determine the relationships among the different types of cells, we examined 50 serial ultrathin sections per SVZ site. The classification of cell types was based on 1800 cells from sites throughout the SVZ. Cross-sectional areas were determined for the different cell types as an indication of cell size (Table 1). The largest cross-sectional profile for individual cells in serial sections was drawn and its area calculated with National Institutes of Health Image analysis software.

Reconstructions. Four different regions in the walls of the lateral ventricle were reconstructed serially and examined under the electron microscope. Three regions were in the lateral wall [dorsolateral aspect (15 levels), intermediate aspect (15 levels), and ventral aspect (25 levels)] and one in the medial wall [ventral aspect (25 levels)]. Serial sections were cut with a diamond knife in the following order: one $1.5 \mu \mathrm{m}$ semithin section, followed by ten $0.05 \mu \mathrm{m}$ ultrathin sections. Each $2 \mu \mathrm{m}$ unit $(1$ semithin section and 10 ultrathin sections) represented one of 15 or 25 levels studied in the reconstructions. Of the levels, 10 of 15 for the dorsolateral region are presented in Figure 5 (see below). Semithin sections were stained with $1 \%$ toluidine blue; ultrathin sections were placed on Formvar-coated single-slot grids and stained with lead citrate. Areas in each of the four regions were selected and photographed (dorsal lateral wall, $150 \times 30 \times 22 \mu \mathrm{m}$; intermediate lateral wall, $100 \times 30 \times 22 \mu \mathrm{m}$; ventral lateral wall, $80 \times 40 \times 22 \mu \mathrm{m}$; ventral medial wall, $80 \times 40 \times 22$ $\mu \mathrm{m})$. Photo montages of each level were assembled, and the outlines of individual cells were traced with color markers onto acetate sheets (see Fig. 4). Each cell type was traced in a different color. Computer digitizations then were made of 10 of the 15 levels studied in the dorsolateral aspect of the lateral wall and 10 of the 15 levels studied in the intermediate aspect of the lateral wall (data not shown). Reconstructions (see Fig. 4) were made by scanning the composite acetates sheets from each level into the computer. Individual cell types within a level were highlighted by Adobe Photoshop and converted into vector maps with Adobe Streamline. Then vector maps were assembled into a composite reconstruction of each level with Macromedia Freehand.

$\left[{ }^{3} H\right]$ thymidine autoradiography. Five adult male and female CD-1 mice 
Table 2. Number of cells of different types in the lateral wall of the anterior horn of the lateral ventricle $(0-1 \mathrm{~mm}$ anterior to bregma)

\begin{tabular}{|c|c|c|}
\hline CELL TYPE & $\begin{array}{l}\text { DIRECT } \\
\%\end{array}$ & $\begin{array}{c}\text { RECONSTRUCTION } \\
\%\end{array}$ \\
\hline A & $33.29 \% \quad(241)$ & $34.01 \% \quad(150)$ \\
\hline$B$ & $22.93 \% \quad(166)$ & $24.72 \% \quad(109)$ \\
\hline $\mathrm{C}$ & $10.91 \% \quad(79)$ & $9.98 \% \quad(44)$ \\
\hline Ependymal & $28.04 \% \quad(203)$ & $21.32 \% \quad(94)$ \\
\hline Tanycyte & $0.55 \% \quad(4)$ & $1.59 \% \quad(7)$ \\
\hline Mitosis & $0.55 \% \quad(4)$ & $1.59 \% \quad(7)$ \\
\hline Neuron & $1.38 \% \quad(10)$ & $2.04 \% \quad(9)$ \\
\hline Microglia & $1.52 \%(11)$ & $1.13 \% \quad(5)$ \\
\hline Pyknotic & $0.14 \% \quad(1)$ & $0 \%(0)$ \\
\hline Unidentified & $1.93 \%(14)$ & $3.63 \% \quad(16)$ \\
\hline Total & $100 \% \quad(724)$ & $100 \% \quad(441)$ \\
\hline
\end{tabular}

The table indicates percentages and, in parentheses, the absolute numbers of cells counted. The number of profiles counted in individual ultrathin sections at the electron microscope (direct method) is compared with those obtained by counting cells in serial reconstructions (reconstruction method). The counts using the reconstruction method are not biased by cell splitting. However, notice that the direct method yields very similar percentages to those obtained from the reconstructions, except for the ependymal cells that are over-represented because of their significantly larger size (see Table 1).

received one $50 \mu$ injection of $1 \mathrm{mCi}\left[{ }^{3} \mathrm{H}\right.$ ]thymidine intraperitoneally and were killed $1 \mathrm{hr}$ later; the brains were processed as for conventional electron microscopy. Serial $1.5-\mu \mathrm{m}$-thick semithin sections were cut with a glass knife and mounted onto slides, dipped in autoradiographic emulsion (Kodak NTB2), exposed for 4 weeks at $4^{\circ} \mathrm{C}$, developed in Kodak $\mathrm{D}-19$, and counterstained with $1 \%$ toluidine blue. A cell was considered labeled if six or more silver grains overlaid the nucleus and the same cell was labeled in three adjacent sections. Seventy-nine $\left[{ }^{3} \mathrm{H}\right]$ thymidinelabeled cells identified in the semithin sections were selected for electron microscopic examination. Semithin sections were glued (Krazy glue) to Araldite blocks and detached from the glass slide by repeated freezing (in liquid nitrogen) and thawing. The block with the flat semithin section was mounted in the ultramicrotome. Ultrathin sections were cut with a diamond knife and examined under a Jeol 100CX electron microscope to determine which cell types incorporated $\left[{ }^{3} \mathrm{H}\right]$ thymidine.

Cell counts. The proportion of the different cell types in the SVZ of the lateral wall of the lateral ventricle was estimated by two methods. (1) Individual cells were identified in serial ultrathin sections, and the num- ber of the different types of cells was calculated. This method is based on serial section reconstructions providing an accurate determination of cell number that is not affected by section thickness or cell size. (2) The number of profiles corresponding to the different cell types along the dorsoventral extent of the SVZ (lateral wall) was counted at the electron microscope. This analysis was done at different rostrocaudal levels of the lateral ventricle (see Table 3 ). These numbers are presented uncorrected and may be biased by cell size, orientation, and section thickness. However, as shown in Table 2, the proportions of the different cell types calculated by serial section reconstruction and profile counting in single sections were remarkably similar. This indicates that given the size, geometry, and orientation of the different cell types in the wall of the lateral ventricle, the number of profiles exposed in ultrathin electron microscopic sections was a fair representation of the composition of the SVZ.

Immunocytochemistry. Sections $60 \mu \mathrm{m}$ thick were cut on the vibratome and were processed for pre-embedding immunostaining as follows.

For polysialylated neural adhesion cell molecule (PSA-NCAM) immunostaining, vibratome sections were incubated in $0.1 \mathrm{M} \mathrm{NaIO}_{4}$ for $10 \mathrm{~min}$ and $1 \% \mathrm{NaBH}_{4}$ for $10 \mathrm{~min}$, followed by a $30 \mathrm{~min}$ incubation in $5 \%$ DMSO. Sections were washed three times for $10 \mathrm{~min}$. Sections were blocked for $1 \mathrm{hr}$ in $10 \%$ goat serum, incubated $48 \mathrm{hr}$ at $4^{\circ} \mathrm{C}$ with 1:2000 anti-meningococcus B (recognizes PSA-NCAM; gift of G. Rougon, Université Aix-Marseille II, France), washed, and incubated for $24 \mathrm{hr}$ in secondary anti-IgM coupled to peroxidase. The sections were washed, and antibody staining was revealed with $0.02 \%$ diaminobenzidine (DAB) and $0.01 \% \mathrm{H}_{2} \mathrm{O}_{2}$.

For TuJ1 immunostaining, sections were sonicated for $10 \mathrm{sec}$ in PBS, blocked in $10 \%$ normal horse serum, and incubated for $48 \mathrm{hr}$ at $4^{\circ} \mathrm{C}$ in 1:500 anti-TuJ1 antibody (gift of A. Frankfurter, University of Virginia) in blocking solution. Sections were washed, incubated in 1:200 antimouse-biotinylated secondaries (Vector Laboratories, Burlingame, CA) for $24 \mathrm{hr}$ at $4^{\circ} \mathrm{C}$, washed, incubated for $4 \mathrm{hr}$ in $\mathrm{ABC}$ (Vector), and revealed with $\mathrm{DAB}$ as above. For vimentin immunostaining, sections were blocked in $3 \%$ BSA, incubated for $48 \mathrm{hr}$ at $4^{\circ} \mathrm{C}$ with $1: 1$ anti $40 \mathrm{E}-\mathrm{C}$ (Alvarez-Buylla et al., 1987), and revealed with biotinylated secondaries as above. For GFAP immunostaining sections were blocked in $10 \%$ normal horse serum and $0.2 \%$ gelatin, incubated for $48 \mathrm{hr}$ at $4^{\circ} \mathrm{C}$ in $1: 400$ anti-GFAP antibodies (Sigma, St. Louis, MO), and revealed with biotinylated secondary antibodies as above. For nestin immunostaining, sections were blocked for $1 \mathrm{hr}$ in $10 \%$ horse serum and incubated for $48 \mathrm{hr}$ at $4^{\circ} \mathrm{C}$ in either 1:1 in anti-rat 401 (gift of R. McKay, National Institutes of Health, Bethesda, MD) or 1:2000 anti-nestin 130 (gift of U. Lendahl, Karolinska Institute). Sections were washed three times and incubated for $24 \mathrm{hr}$ in either 1:200 anti-mouse (anti-401) or 1:400 anti-rabbitbiotinylated secondaries (anti-nestin 130) and revealed with DAB as above.

Immunostained sections were washed in maleate buffer, post-fixed in $1 \%$ osmium in $0.1 \mathrm{M} \mathrm{PB}$, dehydrated, and embedded in Araldite (Durcupan, Fluka). Two-micron-thick semithin sections were cut with a glass knife and stained with $1 \%$ toluidine blue, re-embedded as described above for ultrathin sectioning, and examined under a Jeol 100CX electron microscope.

\section{RESULTS}

The SVZ of the adult mouse brain is a discontinuous layer of dark and light cells next to the ependymal lining. This layer is most evident in the lateral wall of the lateral ventricle facing the striatum (Mitro and Palkovits, 1981). The medial wall facing the septum is largely devoid of SVZ, with the exception of the most anterior part of the anterior horn, where dark and light cells similar to those in the lateral wall are found. The roof of the lateral ventricle is almost devoid of SVZ. This study focuses on

Figure 1. Cell types in the SVZ of adult mice. The identification of the different cell types was made in serial reconstructions, and not all ultrastructural features are present in each photomicrograph. $A$, Three Type A cells $(a)$ showing scant, dark cytoplasm with many free ribosomes, a small Golgi apparatus (arrow), and dense heterochromatin. The surface of Type A cells is relatively smooth. Their elongated shape is not visible in this cross section. Type A cells frequently are separated by open extracellular spaces (asterisks) and are joined by specialized junctional complexes (see Fig. 2). Magnification, $10,500 \times . B$, Type B1 (b) cells have light cytoplasm, dense bodies, thick bundles of intermediate filaments (arrow), and irregular contours that penetrate the intercellular space around them. Type B1 cells are located at the interface between ependymal cells (e) and overlying tissue. (Figure legend continues) 

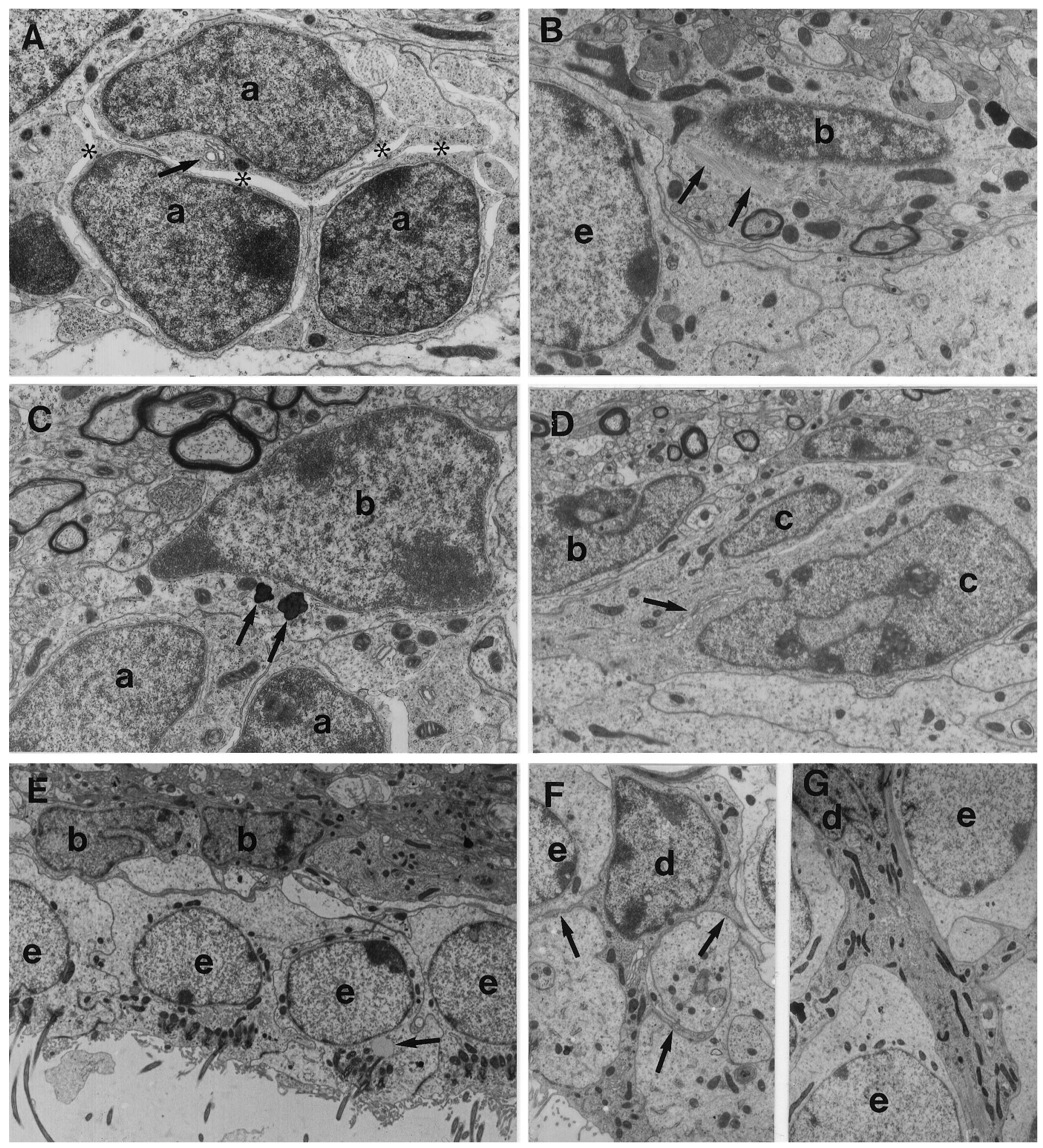

Magnification, 13,000×. C, Type B2 cells have light cytoplasm, irregular contours, and dense bodies in their cytoplasm (arrows). The cytoplasm of Type B2 cells contains few free ribosomes. Type B2 cells $(b)$ are localized basally at the interface of the striatal parenchyma and Type A cells $(a)$. Notice contacts of Type B2 cells with myelinated and unmyelinated axons of the striatal parenchyma. Magnification, $8000 \times . D$, Type C cells $(c)$ have irregular nuclei with deep invaginations, mostly lax chromatin, and a large, reticulated nucleolus. The cytoplasm is more electron-dense than that of Type B cells $(b)$ and contains a clear Golgi apparatus (arrow). Magnification, 6500×. E, Ependymal cells $(e)$ line the ventricle and frequently are ciliated. They are heavily interdigitated and contain apical junctional complexes. Their nuclei are round and their chromatin unclumped. Their cytoplasm is very light and contains many basal mitochondria and a few free ribosomes. Lipid droplets (arrow) are unique to ependymal cells. Note two Type B cells $(b)$. Magnification, $3800 \times$. $F, G$, Tanycytes $(d)$ are dark, unciliated cells that contact the ventricle. They have irregular nuclei and an electron-dense cytoplasm containing many mitochondria and a large Golgi apparatus. They exhibit lateral branches (arrows) that interdigitate with ependymal cells (e) and Type B cells. Magnification: $6000 \times$ in $F ; 4500 \times$ in $G$. 

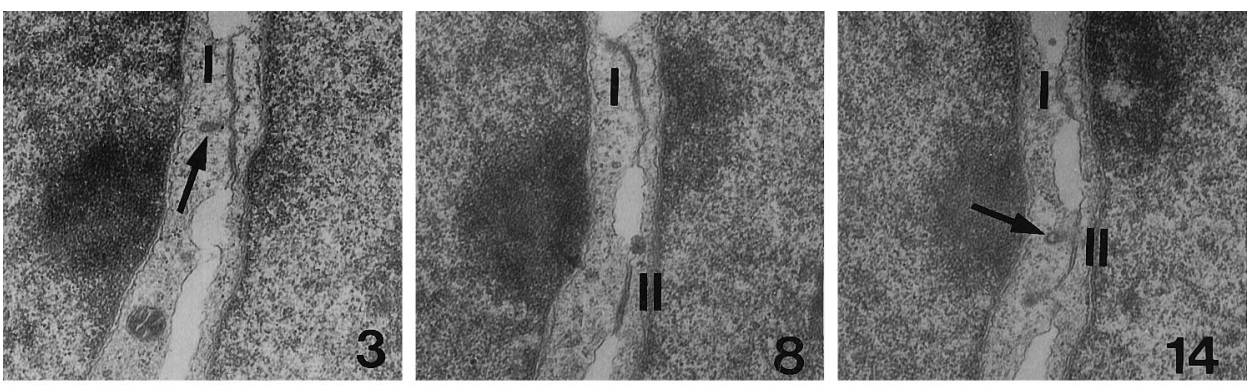

Figure 2. Selected sections of a serial reconstruction of small zonula adherens-like contacts between Type A cells. The junctions between two Type A cells were photographed in 39 ultrathin serial sections; section number is indicated in the lower right corner. Four junctions $(I, I I, I I I, I V)$ appear in this reconstruction. The junctions are not continuous but are disk-like in shape with a diameter of $\sim 0.5-1 \mu \mathrm{m}$. Endocytic vesicles (arrows) frequently were associated with these junctions. Magnification, 12,500×.
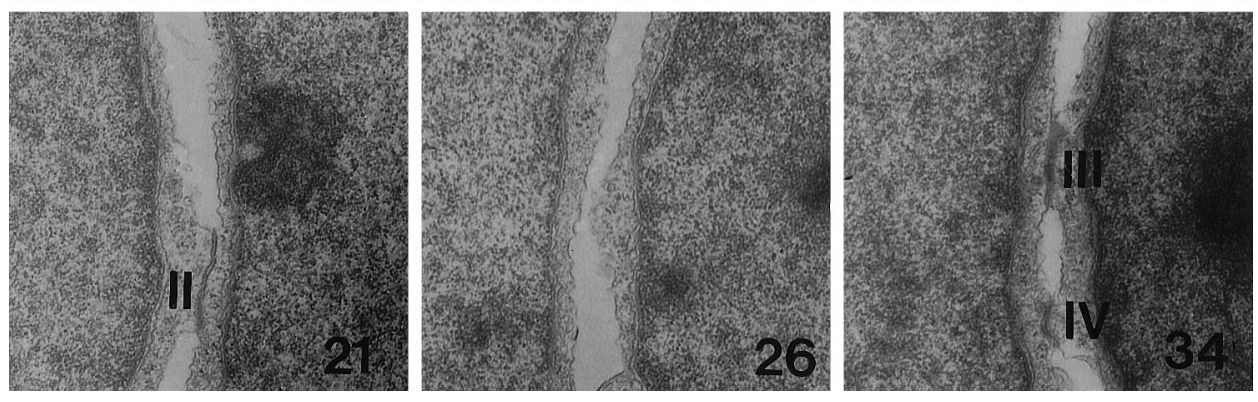

the SVZ facing the striatum and encompasses the entire dorsoventral extent of this lateral wall at multiple rostrocaudal levels.

\section{Multiple cell types coexist in the adult SVZ}

The ultrastructural characteristics of the different cell types described below were determined in serial section reconstructions of individual cells. Not all features are present in a single section. Table 1 summarizes the ultrastructural characteristics of the different cell types.

Type A cells corresponded to the dark cells visible at the light microscope. The morphology of these cells (see Figs. 1A, 3) was similar, if not identical, to the migrating neuronal precursors (Type A cells) described in the RMS (Lois et al., 1996). Their major characteristics were an elongated cell body with one or two processes, abundant lax chromatin with two to four small nucleoli, and a scant, dark cytoplasm containing many free ribosomes, a few short cisternae of rough endoplasmic reticulum (RER), a small Golgi apparatus, and many microtubules oriented along the long axis of the cells. The nuclei of Type A cells occasionally were invaginated. Type A cells had smooth contours and were joined to other Type A cells by small junctional complexes. Serial sectioning revealed that these junctional complexes were circular, with a diameter of $0.5-1 \mu \mathrm{m}$ (Fig. 2), and were distributed over the cell surface. Interestingly, endocytic vesicles were observed very frequently within the junctional complexes. These endocytic vesicles may correspond to sites of exchange of signals between cells or could be related to the removal of the junctional complexes (Privat, 1974). In frontal sections Type A cells had the smallest cross-sectional area (Table 1).

Type B cells (Fig. 1B,C) had irregular contours that profusely filled the spaces between neighboring cells. These cells had irregular nuclei that frequently contained invaginations (Fig. 1E). The cytoplasm of Type B cells was light and contained few free ribosomes. Salient characteristics of Type B cells were their abundant intermediate filaments (Fig. $1 B$ ) and dense bodies in the cytoplasm (Fig. 1C). Among Type B cells there were two subtypes, Type B1 and B2. Type B1 astrocytes were lighter, had more cytoplasm, and were larger than Type B2 cells (Fig. 8C, Table 1). In addition, the chromatin in the nuclei of Type $\mathrm{B} 2$ astrocytes was clumped, whereas in Type B1 cells the chromatin was relatively dispersed (Fig. 3A). Type B1 cells were similar in ultrastructure to the Type B cells previously described in the RMS (Lois et al., 1996). Type B1 cells were most common adjacent to ependymal cells, where they extended many processes to form a lamina covering the ependymal layer. In contrast, Type B2 cells were localized most frequently at the interface with the striatal parenchyma. Regardless of the differences between these two cell types, both had ultrastructural (Peters et al., 1991) and immunocytochemical (see below) characteristics of astrocytes.

We distinguished a third cell type, which we call Type $\mathrm{C}$ (Figs. $1 D, 3 A, D, 8 A$ ), that differed from both Type A cells (putative migrating cells) and Type B cells (astrocytes). Type C cells were larger, more spherical (less elongated), and more electron-lucent than Type A cells but more electron-dense than Type B cells. Their nuclei contained deep invaginations (Fig. $1 D$ ) and mostly lax chromatin, although sometimes the chromatin was clumped. Type $\mathrm{C}$ cells had an atypical, large reticulated nucleolus (Fig. 3A). Their cytoplasm contained a large Golgi apparatus (Fig. 1D), fewer ribosomes than Type A cells, and no bundles of intermediate filaments typical of Type B cells. The contour of Type $\mathrm{C}$ cells was smooth, and these cells frequently contacted Type A cells. Occasionally, small junctional complexes, similar to those described between Type A cells (Fig. 2), were observed between Type C and Type A cells. Type $\mathrm{C}$ cells were similar in size to Type B1 cells (Table 1) but had fewer processes.

Tanycytes (Type D cells) were infrequent in the regions studied. These unciliated cells were wedged between ependymal cells, contacted the ventricle, and contained microvilli on their luminal surface. These cells had profuse lateral extensions between ependymal cells (Fig. $1 F, G$ ). Their nuclei were irregularly shaped and contained dark chromatin aggregates. The cytoplasm of these cells was electron-dense and rich in organelles containing many mitochondria, lysosomes, abundant RER, and a distinct Golgi apparatus.

The large ependymal (Type E) cells formed an epithelial monolayer separating the SVZ from the ventricular cavity (Fig. $1 E)$. The structure of these cells has been described before by many investigators (for review, see Peters et al., 1991). Their 

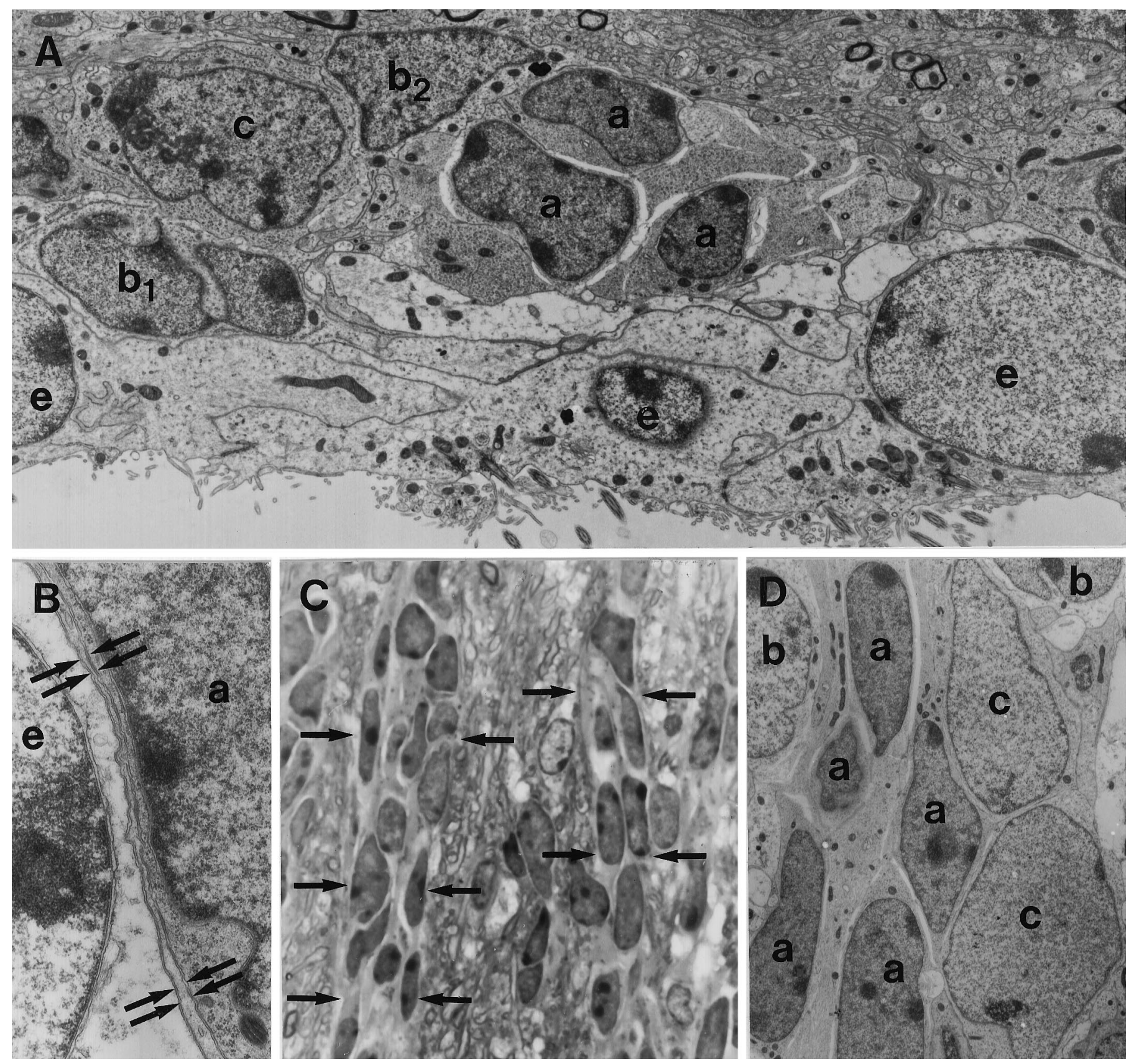

Figure 3. Relationships among the major cell types in the SVZ. Identification of the individual cell types was made in serial ultrathin sections. $A$, Frontal section through the SVZ in the lateral wall revealing the topographical relationships of the different cell types to one another. A transversely cut chain of Type A $(a)$ cells is separated from ependymal cells $(e)$ by the electron-lucent lateral expansions of Type B1 cells $\left(b_{1}\right)$, which are found adjacent to the ependymal layer. In contrast, the processes of Type B2 cells $\left(b_{2}\right)$, which are localized basally adjacent to the striatal parenchyma, isolate the chain of Type A cells from the surrounding neuropil. Type B cells are never found inside chains. Notice the clumped chromatin typical of Type B2 cells and the unclumped chromatin of Type B1 cells. A Type C cell $(c)$ with its typical reticulated nucleolus is located close to the chain of Type A cells. Magnification, $6700 \times$. B, A thin lamina (arrows) formed by individual or multiple processes of Type B1 cells separate Type A cells $(a)$ from ependymal cells $(e)$. Magnification, 16,800×.C, Tangential section through the SVZ showing the chain organization of Type A cells at the light microscope in a semithin section. The arrows indicate the presence of two chains of dark cells corresponding to Type A cells. Magnification, $360 \times . D$, Tangential section through the SVZ showing the elongated shape of Type A cells in this plane and their close association with Type C cells. The larger size of Type C cells is clearly visible here, as are the differences in cytoplasmic electron density of Type A, B, and C cells. $a$, Type A cell; $b$, Type B cell; $c$, Type C cell. Magnification, $3500 \times$.

main distinguishing characteristics were as follows: the lateral processes of adjacent ependymal cells were heavily interdigitated (Figs. $1 E, 3 A$ ) and contained apical junctional complexes. The surface exposed to the ventricular cavity contained microvilli and frequently was ciliated. The cytoplasm was electron-lucent and contained many mitochondria and basal bodies located in the apical cytoplasm. Their nuclei were spherical, and the chromatin was nonclumped.

In addition, microglia, a few pyknotic cells, mitoses, and large neurons were observed sporadically in the SVZ. 
A

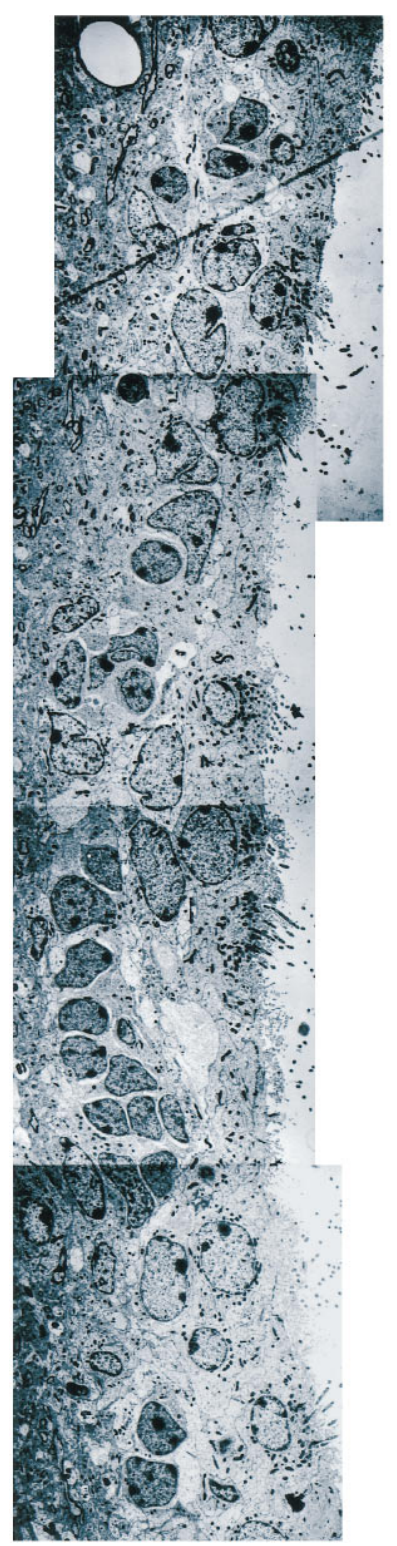

B

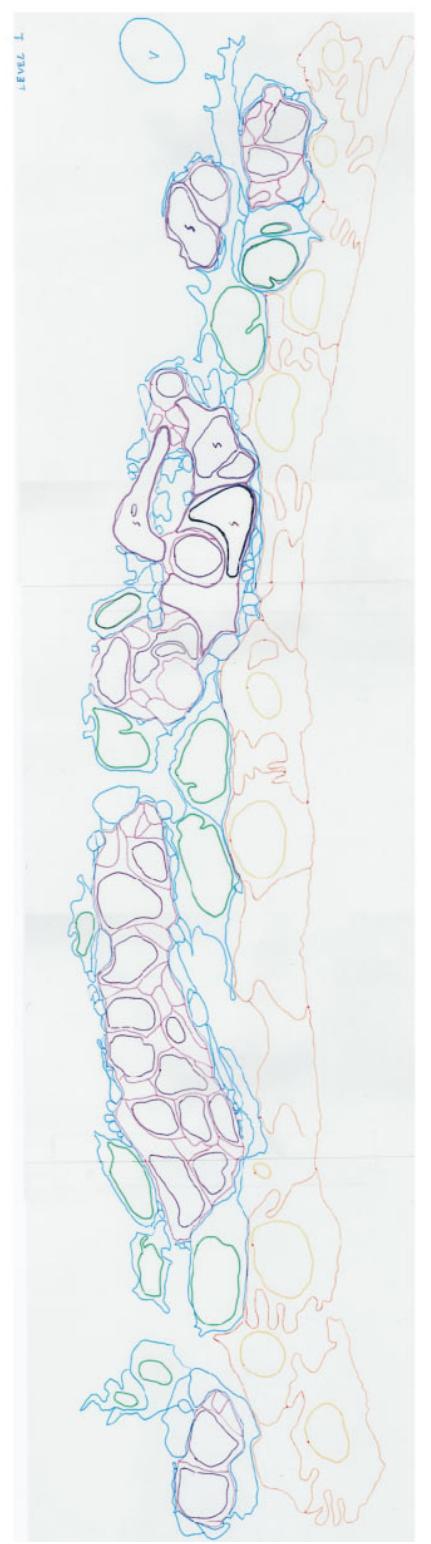

C

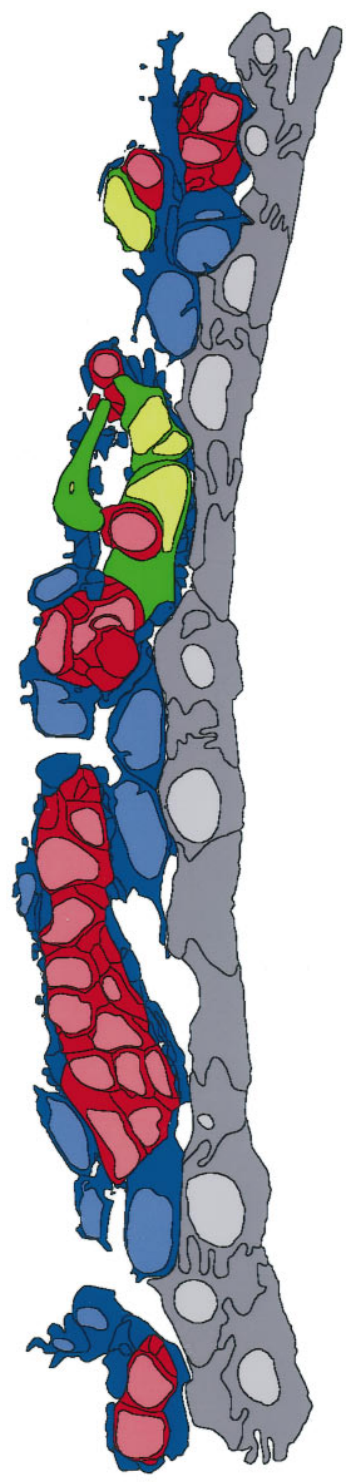

Figure 4. Steps in the extraction of information about SVZ cell arrangement. $A$, Contiguous electron micrographs of the SVZ were assembled into a photo montage. $B$, The contours and nuclei of the different cell types were traced in different colors. $C$, This information was transferred into a computer, and cells were filled as described in Materials and Methods. This SVZ representation allowed identification of cell types at a glance and the interpretation of serial section reconstructions presented in Figure 5.

\section{Three-dimensional reconstruction reveals the topographical organization of the different cell types}

To determine the number of, and relationships among, the different cell types, we reconstructed the SVZ at the electron microscope. The lateral wall of the lateral ventricle was reconstructed at three dorsoventral locations. The fourth reconstruction was of the medial wall. The contours of individual cells were traced and digitized as described in Figure 4. Only one reconstruction is presented (Fig. 5) that corresponds to the dorsolateral SVZ.

Ependymal cells formed a continuous sheet of epithelial cells covering the brain ventricles (dark gray cells with light gray nuclei in Fig. 5). In individual ultrathin transverse sections of the SVZ,

Figure 5. Serial section (separated by $2 \mu \mathrm{m}$ ) reconstruction of the dorsolateral aspect of the lateral wall of the lateral ventricle at the level indicated by the arrow in the coronal hemisection (bottom left). Cell types were identified in photo montages on the basis of characteristics described in the text. The contours and processes of cells were drawn and transferred into drawing programs as described under Materials and Methods and illustrated in Figure 4. Colors corresponding to the different cell types are indicated in the key. In this portion of the ventricle the chains of migrating cells (Type A cells) are very abundant. Type A cells (red) form continuous chains that branch and converge. These chains are covered mainly by Type B cell processes (blue) and frequently are associated with clusters of Type C cells ( green). Empty spaces are areas of dense neuropil. Nc, Neocortex; $c c$, corpus callosum; $S t$, striatum; $L V$, lateral ventricle. Scale bar, $20 \mu \mathrm{m}$. 


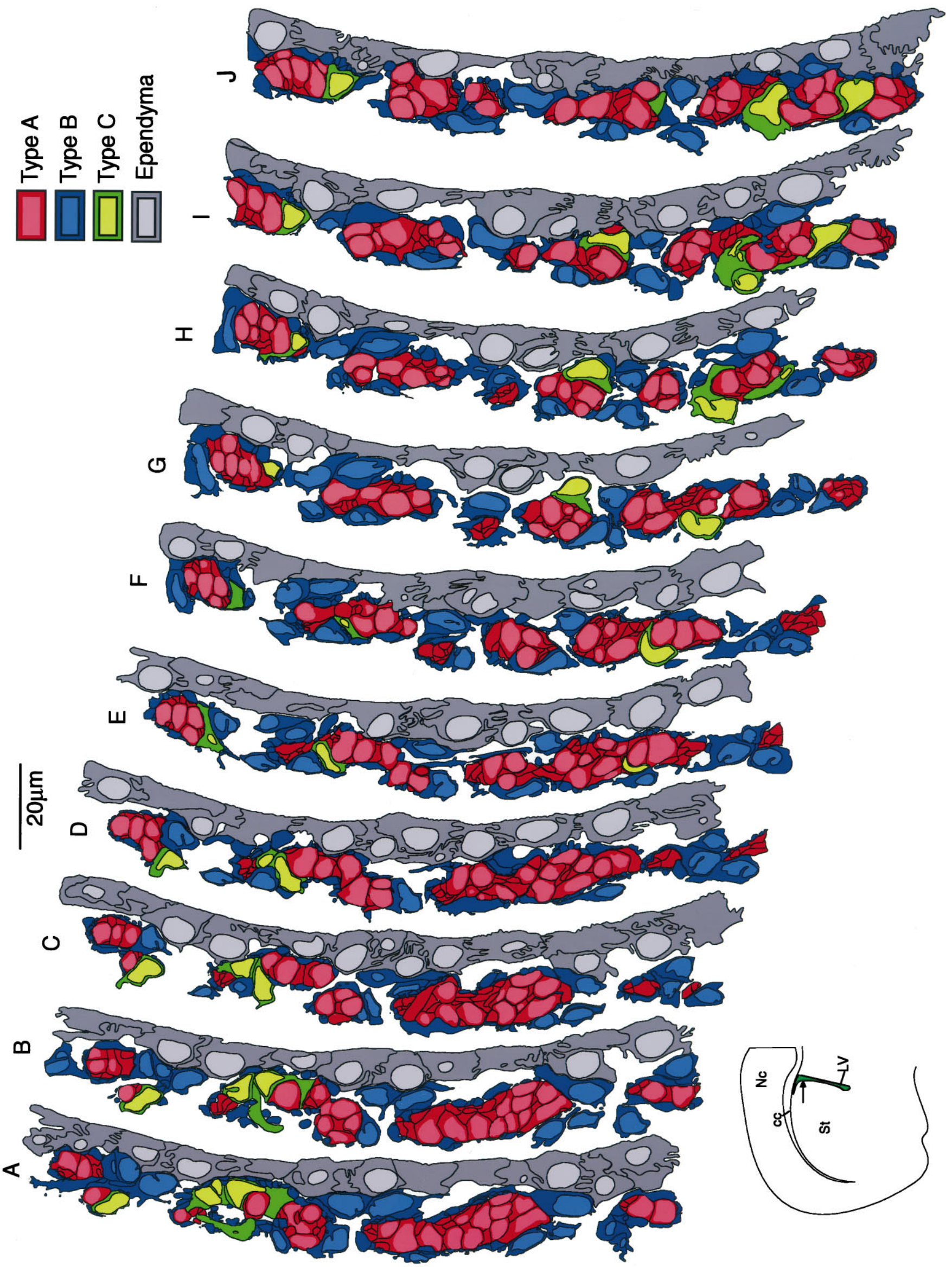


Table 3. Proportion of different cell types at various rostrocaudal levels of the SVZ in the lateral wall of the lateral ventricle and in the RMS

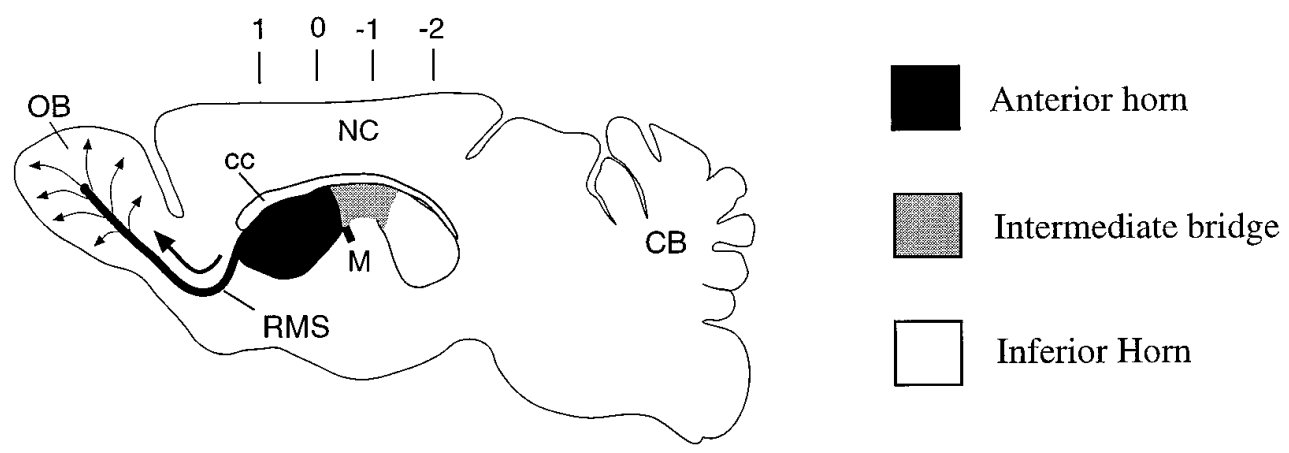

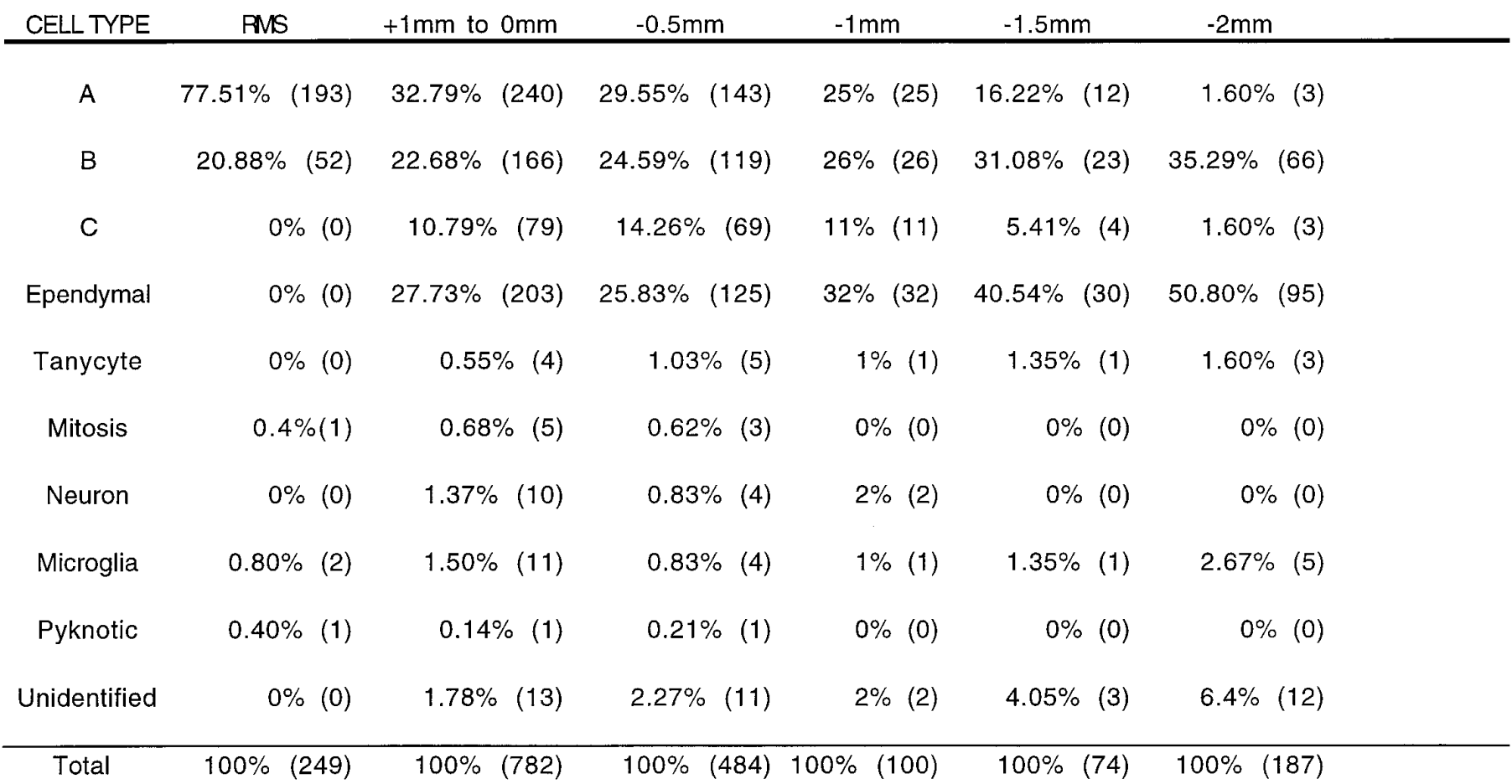

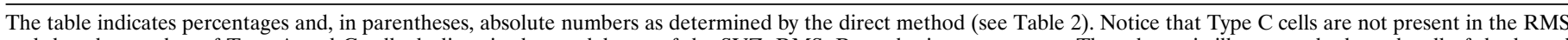

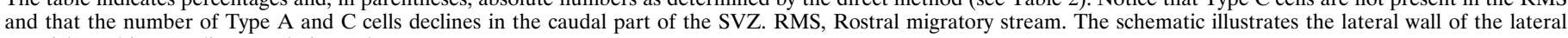
ventricle and its coordinates relative to bregma.

Type A cells (dark red cells with light red nuclei in Fig. 5) appeared in clusters one to four cells wide (mediolateral) and 2-30 cells long (dorsoventral) (Figs. 3A,C, 5). However, when they were examined in serial reconstructions, these clusters of Type A cells were observed to correspond to chains of cells extending over multiple sections. These tangentially oriented chains (parallel to the wall of the lateral ventricle) both split into smaller chains or joined others as they traversed anterior-posterior levels of the SVZ (Fig. 5).

The chains of Type A cells were isolated from the striatum and ependymal layer by a feltwork formed by the processes and cell bodies of Type B cells (dark blue cells with light blue nuclei in Fig. 5). A lamina formed by the expansions of Type B1 cells (Fig. 3B) separated chains of Type A cells from the ependymal layer, whereas expansions of Type B2 cells isolated the chains of Type A cells from the overlying striatum. Therefore, Type B1 and B2 cells together ensheathed the chains of migrating cells. Occasionally, small gaps in the sheath between Type A cells and the striatum were left by Type B2 cells. In contrast, gaps in the glial covering (B1) between Type A cells and the ependymal layer were not encountered.

Type C cells (green cells with light green nuclei in Fig. 5) were found most often in small clusters and, occasionally, as individual cells contacting the chains of Type A cells (Fig. 3A,D). However, unlike Type A cells, Type C cells were not isolated from the surrounding parenchyma by Type B cells. Although some were partially covered by Type B processes, Type $\mathrm{C}$ cells contacted both ependymal cells and striatal parenchyma.

One prediction of the above reconstructions (based on serial frontal sections) is that chains of Type A cells should be visible in sections parallel to the ependymal layer. In tangential semithin sections through the SVZ, chains of dark cells were observed (Fig. 3C). At the electron microscope these dark cells corresponded to Type A cells, and the close association of Type $\mathrm{C}$ cells with the chains of Type A cells could be observed (Fig. 3D). 

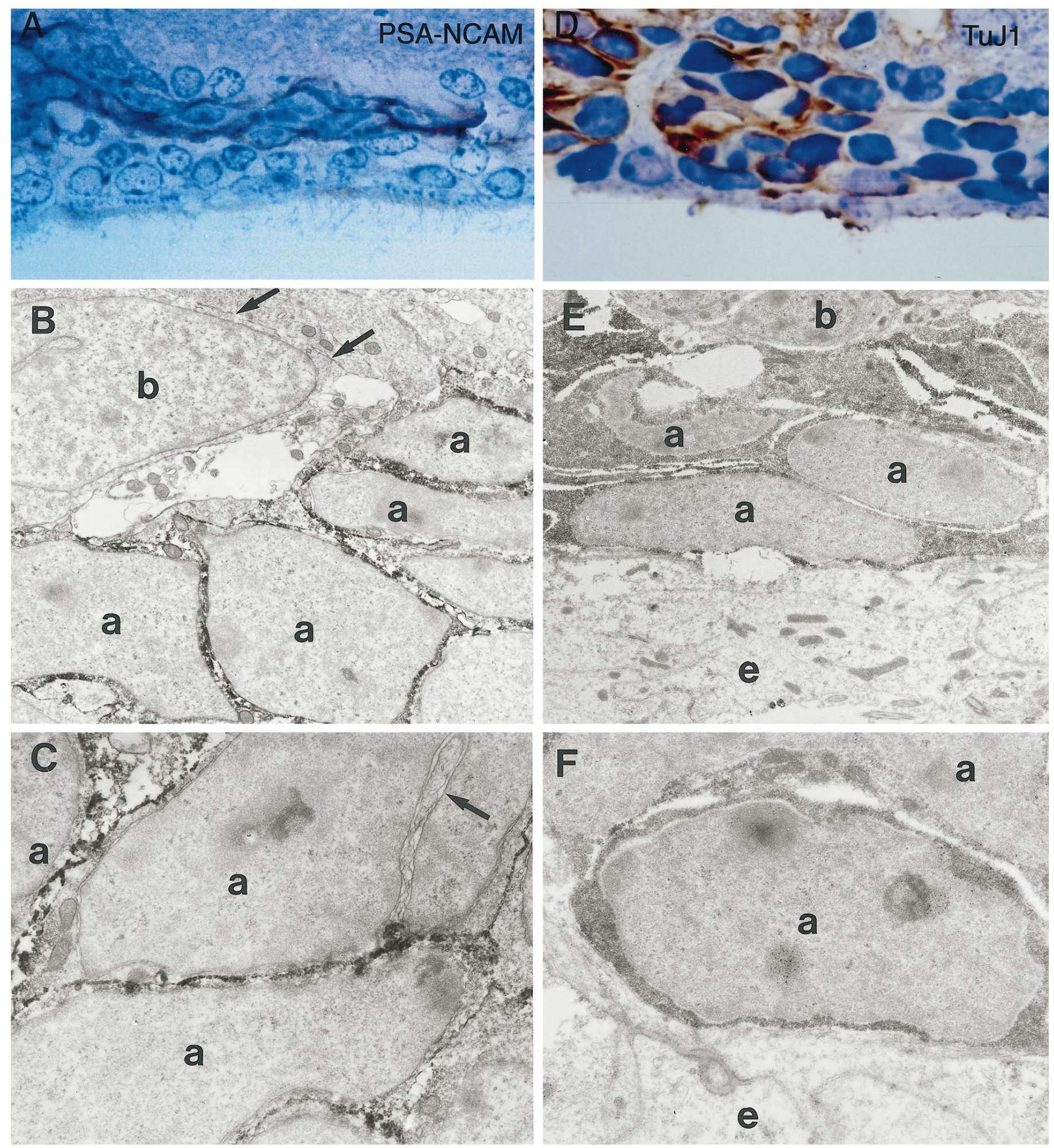

Figure 6. Immunocytochemical characterization of different cell types in the SVZ: PSA-NCAM and TuJ1. The chains of Type A cells are immunopositive for both PSA-NCAM and TuJ1. Other cell types are immunonegative for these markers. A, PSA-NCAM staining in toluidine blue-stained coronal semithin section showing a chain of immunopositive cells flanked by immunonegative cells. Magnification, $400 \times$. $B, C$, Immunostaining for PSA-NCAM at the ultrastructural level. Type A cells are immunopositive for PSA-NCAM, whereas Type B cells are immunonegative (arrows in $B$ ). PSA-NCAM staining is continuous along the plasma membrane of Type A cells $(a)$; nuclear membranes of Type A cells are unstained (arrow in $C$ ). Magnification: $8000 \times$ in $B ; 11,500 \times$ in $C . D$, TuJ1 immunostaining in toluidine blue-stained coronal semithin section. Magnification, $500 \times$. $E$, $F$, Immunostaining for TuJ1 at the ultrastructural level. The cytoplasm of Type A cells is darkly stained by anti-TuJ1 antibodies. Type B cells $(b)$ and ependymal cells $(e)$ are immunonegative for this marker. Magnification: $6800 \times$ in $E ; 12,000 \times$ in $F$. 
Table 4. Immunocytochemical characteristics of cells in the SVZ of adult mice

\section{Type C cells are found throughout the SVZ, but not in the RMS}

To determine the composition of the SVZ, we counted at the electron microscope the number of the different cells in ultrathin sections of the lateral wall of the lateral ventricle in the anterior horn $(0,0.5$, and $1 \mathrm{~mm}$ anterior to bregma). In addition, we counted the number of the different cell types in three reconstructions. The proportion of the different cell types calculated by the two methods was very similar (Table 2). Type A cells were the most common cell type, followed by ependymal and Type B cells. Type C cells represented $\sim 10 \%$ of the cells in this wall. The ratio of Type A:B:C cells was approximately 3:2:1.

The above quantification was made in the anterior horn of the lateral ventricles. Because the SVZ of the lateral wall of the lateral ventricle extends further caudally into the inferior horn (Smart, 1961; Doetsch and Alvarez-Buylla, 1996), we determined the number of the different cell types at $0.5,1.0,1.5$, and $2 \mathrm{~mm}$ caudal to bregma in ultrathin sections. Type A, B, and C cells were found at all rostrocaudal levels studied. The arrangement of cells in the caudal SVZ was similar to that described above, with Type A cells forming chains ensheathed by Type B cells (data not shown). As indicated in Table 3, the proportion of cells at 0.5 and $1 \mathrm{~mm}$ caudal to bregma was similar to that found in the anterior horn. Type A and C cells were found as far caudal as $-2 \mathrm{~mm}$ from bregma. However, there was a noticeable decrease in the number of Type A and C cells at -1.5 and $2.0 \mathrm{~mm}$ caudal to bregma, with the relative numbers of Type B cells increasing. In contrast, the RMS was composed of Type A and B cells (Jankovski and Sotelo, 1996; Lois et al., 1996); of 249 cells sampled in the RMS, none corresponded to Type C cells (Table 3).

\section{Immunocytochemical characterization of the different cell types in the SVZ}

To define further the different cell types in the walls of the lateral ventricles of adult mice, we determined, at the light and electron microscopic level, which cells expressed PSA-NCAM, a protein expressed at sites of neural plasticity (Theodosis et al., 1991) and by migrating neuroblasts in the RMS and SVZ (Rousselot et al., 1995; Doetsch and Alvarez-Buylla, 1996); TuJ1, a marker for $\beta$-tubulin that recognizes young neurons (Easter et al., 1993; Moody et al., 1996); GFAP, a marker of astrocytes (Bignami and Dahl, 1974); vimentin, an intermediate filament expressed by precursor cells (Cochard and Paulin, 1984; Alvarez-Buylla et al., 1987, 1990; Sancho-Tello et al., 1995), glial cells (Schiffer et al., 1986; Cohen et al., 1994) and some neurons (Schwob et al., 1986); and nestin, a neuroepithelial stem cell marker (Lendahl et al., 1990). Table 4 summarizes the immunostaining characteristics of the different cell types.

\section{PSA-NCAM and TuJ1 immunostaining}

Type A cells were darkly stained by anti-PSA-NCAM and TuJ1 antibodies (Fig. 6A-C). PSA-NCAM staining was continuous along the entire plasma membrane of Type A cells, regardless of whether the cell was facing another Type A cell or a Type B or Type C cell. TuJ1 antibodies stained the cytoplasm of Type A cells (Fig. 6D-F). Type $\mathrm{B}$ and $\mathrm{C}$ cells and ependymal cells were negative for both PSA-NCAM and TuJ1 immunostaining.

\section{GFAP, vimentin, and nestin immunostaining}

Type B cells were darkly stained with anti-GFAP antibodies (Fig. $7 A-D$ ) and lightly stained by the vimentin antibodies (Fig. $7 E-G$ ). The processes of Type B1 cells separating the chains of Type A cells from ependymal cells were clearly stained with anti-GFAP antibodies (Fig. 7D). This staining pattern supports our ultrastructural characterization of these cells as astrocytes. Ependymal cells were darkly stained by anti-vimentin antibodies (Fig. 7E, $F$ ) and lightly stained by anti-GFAP antibodies (Fig. 7A,B,D). Tanycytes (Type D cells) stained strongly with anti-GFAP (Fig. 7C). Type A and $\mathrm{C}$ cells were negative to both GFAP and vimentin.

Two different anti-nestin antibodies revealed the same staining

Figure 7. Immunocytochemical characterization of different cell types in the SVZ: GFAP, vimentin, and nestin. Chains of Type A cells are immunonegative for GFAP and vimentin but are immunopositive for nestin. Type B cells, which ensheath the chains of Type A cells, are immunopositive for GFAP, vimentin, and nestin. Ependymal cells are stained very strongly by nestin and vimentin antibodies but more weakly by GFAP antibodies. Shown is immunostaining of GFAP $(A)$, vimentin $(E)$, and nestin $(H)$ in toluidine blue-stained coronal semithin sections of the SVZ. (Figure legend continues) 

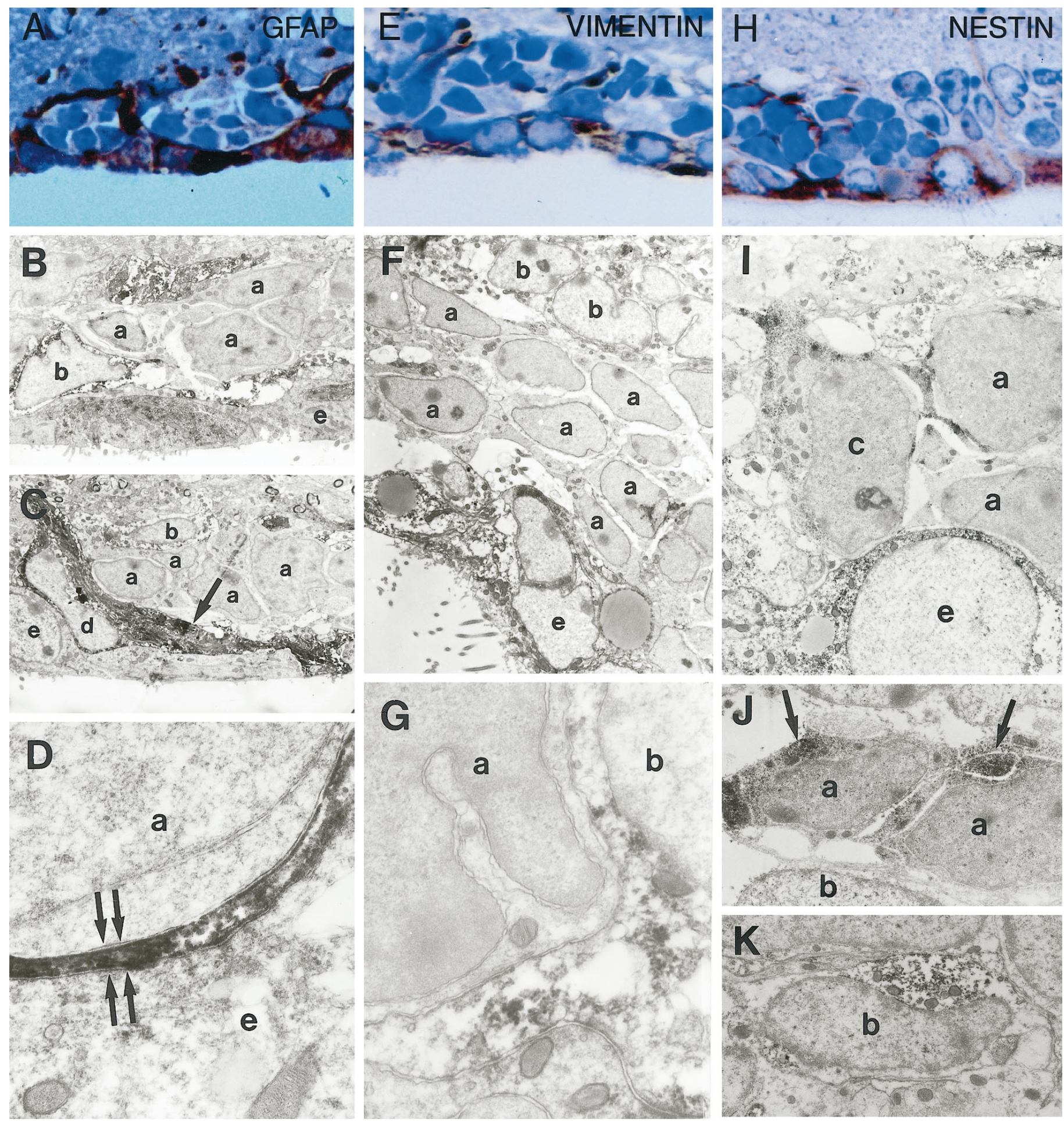

$A$, Clusters of cells in chains are surrounded by processes immunopositive for GFAP. Ependymal cells also are stained by GFAP antibodies. $E$, Ependymal cells are stained strongly by anti-vimentin antibodies. The processes of astrocytes are also vimentin-positive. $H$, Ependymal cells are very darkly stained by nestin antibodies. Staining is also visible in astrocytes and Type A cells (darker nuclei). Magnification: $300 \times$ in $A ; 400 \times$ in $E ; 400 \times$ in $H$. $B$, At the electron microscope the processes and cell bodies of Type B cells $(b)$ are stained by GFAP antibodies. These immunopositive processes surround a chain of Type A cells $(a)$ that are immunonegative for GFAP. Ependymal cells $(e)$ are lightly stained. Magnification, $3000 \times$. $C$, Type D cells $($ tanycytes, arrow) are very darkly stained with GFAP antibodies. Magnification, $2800 \times . D$, Thin lamellar processes (arrows; see also Fig. $2 E$ ) of Type B1 cells that separate Type A cells $(a)$ from ependymal cells $(e)$ are GFAP-positive. Magnification, 26,000×. F, Ependymal cells $(e)$ are strongly immunopositive for vimentin. Type B cells are also positive to vimentin but do not stain as darkly as ependymal cells. Magnification, 3000×. $G$, Higher magnification of vimentin-immunonegative Type A cells adjacent to a vimentin-positive Type B cell $(b)$ with dark immunoreactive precipitate in the cytoplasm. Magnification, 24,500×. I, Nestin immunoreactivity in ependymal cells $(e)$, Type A cells $(a)$, and Type C cells $(c)$. The underlying striatal neuropil and neurons were not stained by the nestin antibody. The cytoplasm of ependymal cells is stained homogeneously, whereas staining is in clumps in Type A and C cells. Magnification, 5000×.J, Clumps of nestin immunoreactivity in Type A cells $(a)$ concentrate in the perinuclear cytoplasm (arrows; see also $I)$. Magnification, $6000 \times . K$, Type B cells $(b)$ also contain nestin immunoreactive material in their cytoplasm. Magnification, $8500 \times$. 
pattern; both labeled multiple cell types. Ependymal cells were stained most strongly (Fig. 7H,I). Type A, B, and C cells were also nestin-positive (Fig. 7I-K). Nestin staining in Type A and C cells appeared as clumps in the cytoplasm (Fig. 7I,J).

\section{Multiple cell types incorporate $\left[{ }^{3} \mathrm{H}\right]$ thymidine in the SVZ of adult mice}

The position and ultrastructural characteristics of cells in mitosis suggested that multiple cell types divide in the SVZ. So that we could determine which cells were dividing, $\left[{ }^{3} \mathrm{H}\right]$ thymidine was injected and animals were killed $1 \mathrm{hr}$ later. Type A, B, and C cells incorporated $\left[{ }^{3} \mathrm{H}\right]$ thymidine (Fig. $8 A-C$ ). Of $79\left[{ }^{3} \mathrm{H}\right]$ thymidinelabeled cells studied at the electron microscope, 41 (52\%) corresponded to Type C cells, 12 (15\%) corresponded to Type A cells, and $10(12 \%)$ corresponded to Type B cells. Sixteen labeled cells $(20 \%)$ could not be identified. Interestingly, all $\left[{ }^{3} \mathrm{H}\right]$ thymidine-labeled Type $\mathrm{B}$ cells corresponded to the B2 subclass; none of the B1 astrocytes encountered incorporated $\left[{ }^{3} \mathrm{H}\right]$ thymidine. Labeled ependymal cells were not observed. $\left[{ }^{3} \mathrm{H}\right]$ thymidine-labeled Type $B$ and Type $C$ cells were found at all dorsoventral levels of the lateral wall of the lateral ventricle. In contrast, $\left[{ }^{3} \mathrm{H}\right]$ thymidine-labeled Type A cells were localized primarily in the dorsolateral aspect and in the ventral aspect of the SVZ but not in the central region.

\section{DISCUSSION}

Our results show how multiple cell types in the SVZ are arranged. The main findings are that (1) the SVZ is organized around chains of neuroblasts (Type A cells) that course tangentially to the walls of the lateral ventricle, (2) neuroblast chains are isolated from ependymal cells and striatum by two types of glial cells (Type B1 and B2), and (3) focal hot spots of proliferating putative precursor (Type C) cells are associated with the migrating neuroblasts only in the SVZ and not in the RMS.

Type A cells correspond to proliferating, migrating neuronal precursors (Lois et al., 1996). They have the same ultrastructural and immunocytochemical characteristics as migrating cells in the RMS (Menezes and Luskin, 1994; Rousselot et al., 1995; Jankovski and Sotelo, 1996; Lois et al., 1996). The three-dimensional reconstruction in this study indicates that clusters of Type A cells correspond to cross-sectional profiles of chains of neuronal precursors, which are part of the extensive network of tangentially oriented chains throughout the SVZ (Doetsch and AlvarezBuylla, 1996). Ultrastructural studies of the SVZ in several mammalian species have described nests of dark cells in frontal sections (Blakemore, 1969; Blakemore and Jolly, 1972; Privat and Leblond, 1972), which are very similar to the clusters of Type A cells we observed here (e.g., Figs. $1 A, 3 A$ ). This suggests that a similar network of chains of migrating precursors probably exists in the SVZ of other vertebrates.

The ultrastructural and immunocytochemical staining characteristics of Type B cells indicate that they are astrocytes. In addition to vimentin and GFAP, Type B cells also express nestin. This intermediate filament has been described in reactive astrocytes and gliomas (Tohyama et al., 1992; Clarke et al., 1994). As in the RMS (Lois et al., 1996), Type B cells in the SVZ formed a tubular trabecula that ensheathed the chains of Type A cells, isolating them from surrounding parenchyma. Unlike the RMS, two subtypes of astrocytes could be distinguished in the SVZ. Type B1 astrocytes separated the chains of Type A cells from the ependymal layer, whereas the basally located Type B2 astrocytes separated the chains of Type A cells from the surrounding striatal parenchyma. The function of the astrocytic sheath around chains, including the intricate insulation from ependymal cells, is not known. Glial cells could channel migration physically along certain routes and may prevent cells from touching the ventricles. Given the extensive distances that Type A cells traverse through different local environments, the glial sheath also may provide trophic support to the migrating cells and may serve to isolate these cells from electrical and chemical influences from surrounding parenchyma.

Chains of Type A cells were found throughout the SVZ, indicating that chain migration is a major component of the adult SVZ. We found no evidence in the three-dimensional reconstructions of radial glia or axonal fibers in the chains, suggesting that, as in the RMS, these neuronal precursors are migrating closely associated to each other. The constant trafficking of neuronal precursors away from the SVZ into the RMS suggests that these cells must be replaced by new cells arising from resident precursors in the SVZ. Cells with stem cell-like properties have been isolated from the adult SVZ. These cells grow in the presence of epidermal growth factor (EGF) (Morshead et al., 1994) or basic fibroblast growth factor (bFGF) (Gritti et al., 1995) to generate spherical clusters of cells, called neurospheres. Neurosphere cells can differentiate into neurons, glia, and oligodendrocytes (Reynolds and Weiss, 1992), suggesting that they arise from a pluripotent precursor and may correspond to in vivo progenitors. The infusion of EGF into the lateral ventricles also results in a dramatic expansion of proliferating cells in the SVZ (Craig et al., 1996). The cells in vivo that correspond to the in vitro stem cells have not been identified. It will be interesting to determine which of the different cell types we describe here give rise to neurospheres and are expanded after EGF infusion. Neurospheres are immunopositive for nestin, a marker of neuroepithelial stem cells in the embryo (Lendahl et al., 1990). Although nestin-positive cells have been observed in the adult SVZ (Morshead et al., 1994; Gates et al., 1995; Craig et al., 1996) with the use of light microscopy, the resolution is insufficient to identify which cell types express this molecule in vivo. We show here that nestin was expressed by various cell types, including ependymal cells and astrocytes (Fig. $8 H-K$ ), suggesting that, in the adult brain, nestin alone cannot be used as an exclusive marker for neural stem cells.

Type C cells, which had immature characteristics (Rhodin, 1974) and were clearly different from Type A and B cells, were found throughout the lateral wall of the lateral ventricle but were not detected in the RMS. Type C cells did not correspond to glial cells; they had smooth contours and undifferentiated cytoplasm, lacked large bundles of intermediate filaments and elaborated processes, and were immunonegative for GFAP and vimentin. In addition, these large cells were immunonegative for PSA-NCAM and $\mathrm{TuJ} 1$, indicating that Type $\mathrm{C}$ cells were different from the migrating neuroblasts. Type $\mathrm{C}$ cells were the most actively proliferating cells in the SVZ $\left(50 \%\right.$ of ${ }^{3}[\mathrm{H}]$ thymidine-labeled cells were Type C cells), expressed the intermediate filament nestin (Lendahl et al., 1990), and contained a characteristic reticulated nucleolus, similar to that found in other precursor cells (HernandezVerdun, 1986). Type C cells often were found in clusters, juxtaposed to the chains of Type A cells (Fig. 5) and occasionally forming specialized contacts with them. These characteristics suggest that Type $\mathrm{C}$ cells correspond to precursors of the neuroblasts in the chains. Glial cells also arise in the SVZ (Levison and Goldman, 1993; Luskin, 1993), but the precursors of these cells are unknown. Although newly generated glial cells could be derived from proliferating Type B2 cells, Type C cells may generate both glia and neurons and, as such, correspond to putative pluripo- 

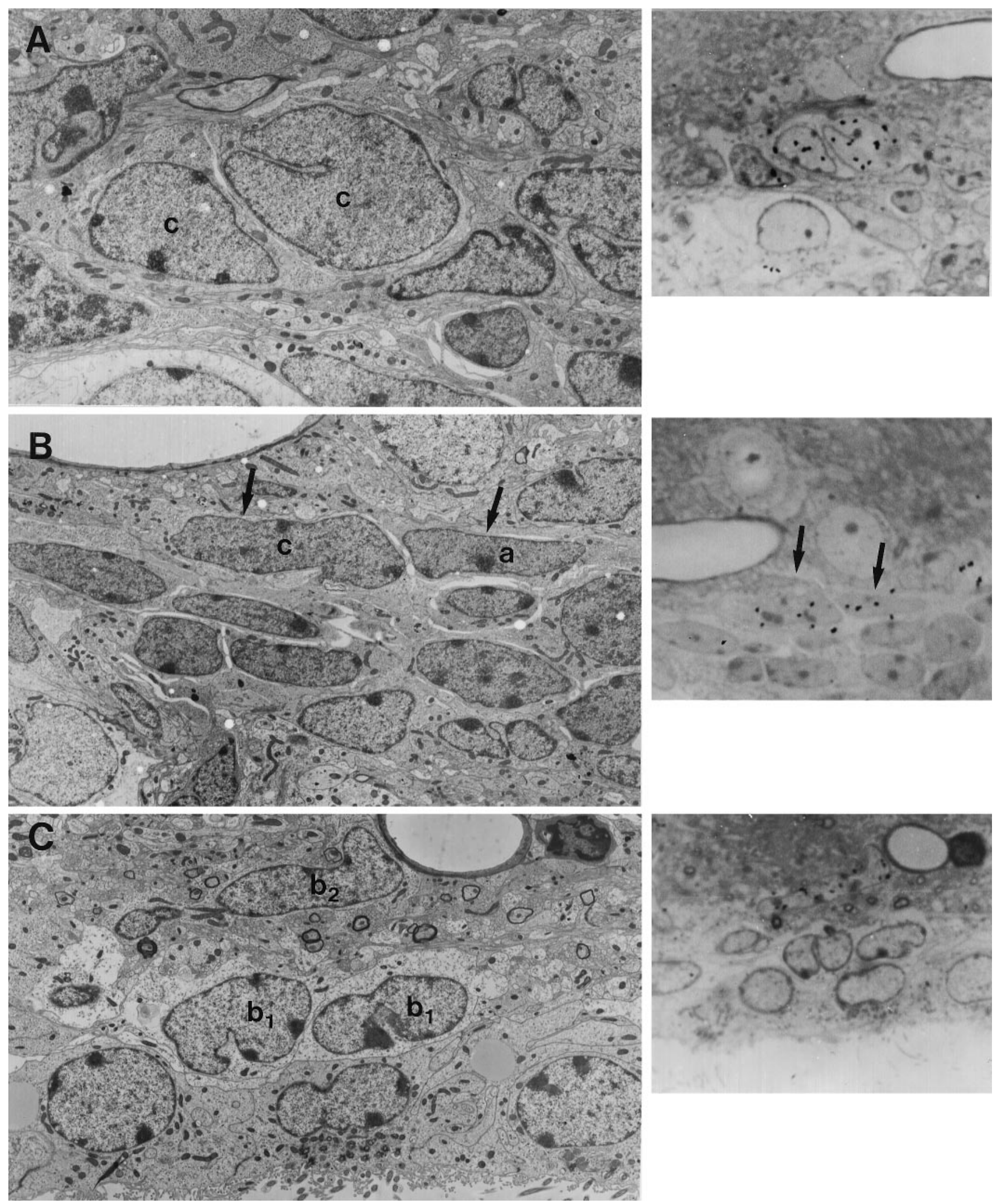

Figure 8. Cell types in the adult mouse SVZ that incorporate $\left[{ }^{3} \mathrm{H}\right]$ thymidine. $A$, Pair of Type $\mathrm{C}$ cells $(c)$ labeled $1 \mathrm{hr}$ after injection of $\left[{ }^{3} \mathrm{H}\right]$ thymidine. Silver grains over the nuclei of these two cells are shown in a semithin section to the right. Magnification, $4500 \times$. B, Two labeled cells $($ arrows in semithin section to the right and in electron micrograph to left) $1 \mathrm{hr}$ after $\left[{ }^{3} \mathrm{H}\right]$ thymidine injection correspond to a Type $\mathrm{C}$ cell $(c)$ and a Type A cell $(a)$. Magnification, $3400 \times$. C, Type B2 cells also were labeled by $\left[{ }^{3} \mathrm{H}\right]$ thymidine $1 \mathrm{hr}$ after injection. In this electron micrograph an elongated Type B2 cell $\left(b_{2}\right.$, arrow $)$ is labeled with silver grains (semithin autoradiogram on the right, arrow). Ependymal cells $(e)$ and Type B1 cells $\left(b_{1}\right)$ were not observed to be labeled with $\left[{ }^{3} \mathrm{H}\right]$ thymidine. Magnification, $3500 \times$. 


\section{A. Transverse}

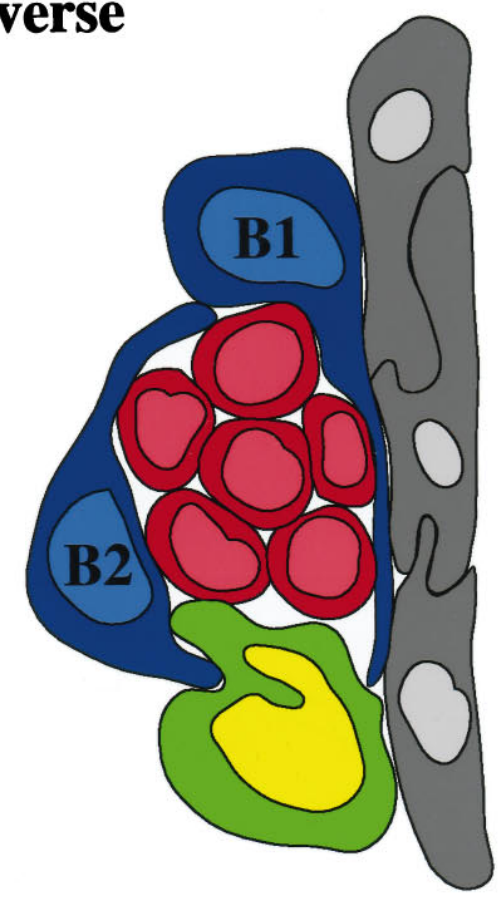

\section{B. Tangential}

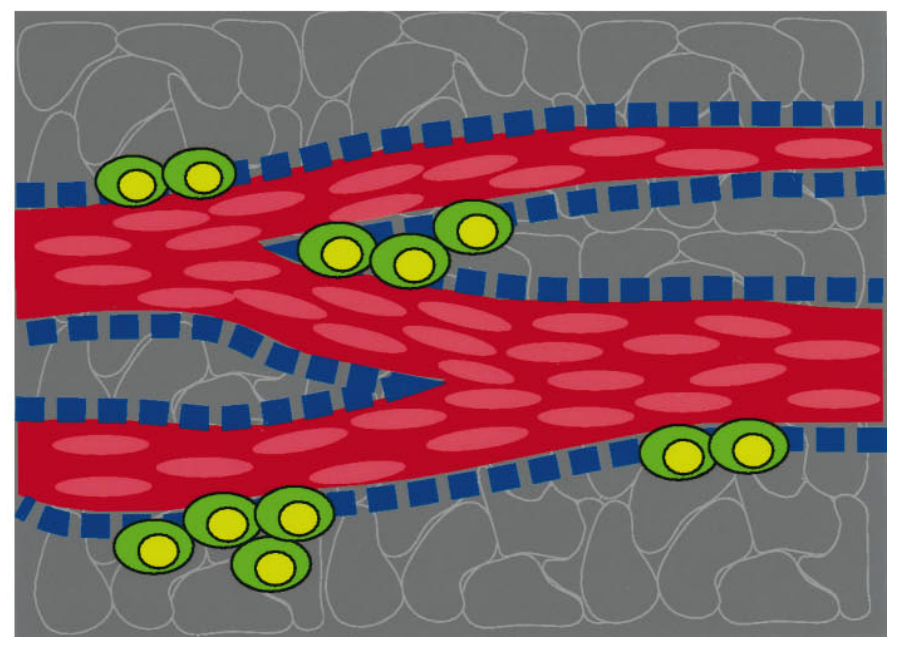

Figure 9. Summary diagram of the organization of the adult SVZ. A, Schematic cross section through a chain of migrating neuroblasts (red) ensheathed by two types of glial cells (B1, B2, blue) that separate the migrating cells from the striatum (left) and ependymal cells (gray). Type $\mathrm{C}$ cells ( green, putative precursor) are not ensheathed by glia and are associated closely with the chains of migrating neuroblasts. $B$, Schematic en face view of the SVZ viewed from the striatum. The red channels represent the chains of migrating neuroblasts (Type A cells) with tangentially elongated nuclei (light red). The blue blocks represent the ensheathing glial cells (Type B1 and B2). These cells form tunnel-like structures through which the Type A cells migrate. Putative precursors (Type C cells, green) are closely associated with - and speckled in small clusters along — chains of migrating neuroblasts. The underlying ependymal cells (gray) form a sheet lining the ventricular surface.

tent precursors. The position of Type $\mathrm{C}$ cells at the periphery of chains, both in contact with Type A and B cells, is consistent with this interpretation. In addition, Type $\mathrm{C}$ cells were not ensheathed by
Type B cells, and their progeny may migrate into brain parenchyma. Although our results suggest that Type $\mathrm{C}$ cells correspond to immature cells, the origin and fate of Type $\mathrm{C}$ cells remain to be determined.

A relatively quiescent cell, in or close to the SVZ, has been proposed to give rise to neurospheres (Morshead et al., 1994). This suggests that Type $\mathrm{C}$ cells are not the neurosphere precursors, because they are very actively dividing. Instead, Type $C$ cells may correspond to an intermediate proliferating population between the relatively quiescent putative stem cell and migrating neuroblasts. Type A and B2 cells also were labeled by $\left[{ }^{3} \mathrm{H}\right]$ thymidine, discarding them as candidates for the relatively quiescent SVZ stem cell. The remaining cell types-ependymal cells, Type B1 cells, and tanycytes-were not observed to incorporate $\left[{ }^{3} \mathrm{H}\right]$ thymidine, but these cells had highly differentiated phenotypes, making them unlikely candidates for putative stem cells. However, whereas ependymal cells are considered terminally differentiated (Bruni et al., 1985), they expressed the highest levels of nestin, and if some were to divide rarely, they would have gone undetected by a single $\left[{ }^{3} \mathrm{H}\right]$ thymidine injection. Therefore, our work does not discard the possibility that some or all ependymal cells may have the capacity to divide and behave as stem cells in vivo. Alternatively, it is possible that cells that give rise to neurons and glia in vivo are not the same as those induced to proliferate in the presence of EGF or bFGF. Multipotent cells from the adult striatum, hippocampus, and other brain regions that do not include SVZ have been isolated in the presence of bFGF (Richards et al., 1992; Gage et al., 1995a; Palmer et al., 1995) or of EGF and bFGF (Weiss et al., 1996a).

Tangential migration is a major function of the adult SVZ. Extensive tangential migration also has been demonstrated in the SVZ earlier in development (Rakic and Sidman, 1969; Halliday and Cepko, 1992; O'Rourke et al., 1995), but its corresponding mechanism is not known. The organization of neurogenesis and migration revealed here for the SVZ of the adult brain also may apply to the embryo. On the basis of the arrangement of Type A, $\mathrm{B}$, and $\mathrm{C}$ cells, we propose that focal clusters of Type $\mathrm{C}$ cells serve as hot spots of precursor proliferation, which give rise to the neuroblasts in the chains (Fig. 9). These foci are sites at which progeny are fed into the network of chains and may indicate regions at which stem cells have divided. Notice that the glial sheath is open where Type C cells are found, strongly suggesting that these are entry points into the network of chains in the SVZ.

The functional interactions among the different cell types in the SVZ, their lineage relationships, and the molecular determinants of neurogenesis in the adult SVZ remain to be uncovered. Here we provide the ultrastructural and immunocytochemical characterization of the different cell types in the adult SVZ and describe their three-dimensional topographical organization. This organization suggests a model of how migration and cell production are integrated functionally in the SVZ and will help to define what types of cell-cell interactions occur in this region.

\section{REFERENCES}

Allen E (1912) The cessation of mitosis in the central nervous system of the albino rat. J Comp Neurol 22:547-568.

Altman J (1969) Autoradiographic and histological studies of postnatal neurogenesis. IV. Cell proliferation and migration in the anterior forebrain, with special reference to persisting neurogenesis in the olfactory bulb. J Comp Neurol 137:433-458.

Alvarez-Buylla A, Lois C (1995) Neuronal stem cells in the brain of adult vertebrates. Stem Cells 13:263-272.

Alvarez-Buylla A, Buskirk DR, Nottebohm F (1987) Monoclonal anti- 
body reveals radial glia in adult avian brain. $\mathbf{J}$ Comp Neurol 264:159-170

Alvarez-Buylla A, Theelen M, Nottebohm F (1990) Proliferation "hot spots" in adult avian ventricular zone reveal radial cell division. Neuron 5:101-109.

Bignami A, Dahl D (1974) Astrocyte-specific protein and neuroglial differentiation. An immunofluorescence study with antibodies to the glial fibrillary acidic protein. J Comp Neurol 153:27-38.

Blakemore WF (1969) The ultrastructure of the subependymal plate in the rat. J Anat 104:423-433.

Blakemore WF, Jolly DR (1972) The subependymal plate and associated ependyma in the dog. An ultrastructural study. J Neurocytol 1:69-84.

Bruni JE, Del Bigio MR, Clattenburg RE (1985) Ependyma: normal and pathological. A review of the literature. Brain Res Rev 9:1-19.

Calof AL (1995) Intrinsic and extrinsic factors regulating vertebrate neurogenesis. Curr Opin Neurobiol 5:19-27.

Clarke SR, Shetty AK, Bradley JL, Turner DA (1994) Reactive astrocytes express the intermediate neurofilament nestin. NeuroReport 5:1885-1888.

Cochard P, Paulin D (1984) Initial expression of neurofilaments and vimentin in the central and peripheral nervous system of the mouse embryo in vivo. J Neurosci 4:2080-2094.

Cohen I, Sivron T, Lavie V, Blaugrund E, Schwartz M (1994) Vimentin immunoreactive glial cells in the fish optic nerve: implications for regeneration. Glia 10:16-29.

Craig CG, Tropepe V, Morshead CM, Reynolds BA, Weiss S, Van der Kooy D (1996) In vivo growth factor expansion of endogenous subependymal neural precursor cell populations in the adult mouse brain. J Neurosci 16:2649-2658.

Doetsch F, Alvarez-Buylla A (1996) Network of tangential pathways for neuronal migration in adult mammalian brain. Proc Natl Acad Sci USA 93:14895-14900.

Easter SS, Ross LS, Frankfurter A (1993) Initial track formation in the mouse brain. J Neurosci 13:285-299.

Gage FH, Coates PW, Palmer TD, Kuhn HG, Fisher LJ, Suhonen JO, Peterson DA, Suhr ST, Ray J (1995a) Survival and differentiation of adult progenitor cells transplanted to the adult brain. Proc Natl Acad Sci USA 92:11879-11883.

Gage FH, Ray J, Fisher LJ (1995b) Isolation, characterization, and use of stem cells from the CNS. Annu Rev Neurosci 18:159-192.

Gates MA, Thomas LB, Howard EM, Laywell ED, Sajin B, Faissner A Gotz B, Silver J, Steindler DA (1995) Cell and molecular analysis of the developing and adult mouse subventricular zone of the cerebral hemispheres. J Comp Neurol 361:249-266.

Gritti A, Cova L, Parati EA, Galli R, Vescovi AL (1995) Basic fibroblast growth factor supports the proliferation of epidermal growth factorgenerated neuronal precursor cells of the adult mouse CNS. Neurosci Lett 185:151-154.

Gritti A, Parati EA, Cova L, Frolichsthal P, Galii R, Wanke E, Faravelli L, Morassutti DJ, Roisen F, Nickel DD, Vescovi AL (1996) Multipotential stem cells from the adult mouse brain proliferate and self-renew in response to basic fibroblast growth factor. J Neurosci 16:1091-1100.

Halliday AL, Cepko CL (1992) Generation and migration of cells in the developing striatum. Neuron 9:15-26.

Hernandez-Verdun D (1986) Structural organization of the nucleolus in mammalian cells. In: Nuclear submicroscopy (Jasmin G, Simard R, eds), pp 26-62. Basel: Karger.

Jankovski A, Sotelo C (1996) Subventricular zone-olfactory bulb migratory pathway in the adult mouse: cellular composition and specificity as determined by heterochronic and heterotopic transplantation. J Comp Neurol 371:376-396.

Johe KK, Hazel TG, Muller T, Dugich-Djordjevic MM, McKay RDG (1996) Single factors direct the differentiation of stem cells from the fetal and adult central nervous system. Genes Dev 10:3129-3140.

Kirschenbaum B, Goldman SA (1995) Brain-derived neurotrophic factor promotes the survival of neurons arising from the adult rat forebrain subependymal zone. Proc Natl Acad Sci USA 92:210-214.

Lendahl U, Zimmerman LB, McKay RDG (1990) CNS stem cells express a new class of intermediate filament protein. Cell 60:585-595.

Levison SW, Goldman JE (1993) Both oligodendrocytes and astrocytes develop from progenitors in the subventricular zone of postnatal rat forebrain. Neuron 10:201-212.

Lois C, Alvarez-Buylla A (1993) Proliferating subventricular zone cells in the adult mammalian forebrain can differentiate into neurons and glia. Proc Natl Acad Sci USA 90:2074-2077.
Lois C, Alvarez-Buylla A (1994) Long-distance neuronal migration in the adult mammalian brain. Science 264:1145-1148.

Lois C, Garcia-Verdugo JM, Alvarez-Buylla A (1996) Chain migration of neuronal precursors. Science 271:978-981.

Luskin MB (1993) Restricted proliferation and migration of postnatally generated neurons derived from the forebrain subventricular zone. Neuron 11:173-189.

Menezes JRL, Luskin MB (1994) Expression of neuron-specific tubulin defines a novel population in the proliferative layers of the developing telencephalon. J Neurosci 14:5399-5416.

Mitro A, Palkovits M (1981) Morphology of the rat brain ventricles, ependyma, and periventricular structures. In: Bibliotheca anatomica, No. 21 (Lierse W, ed). Basel: Karger.

Moody SA, Miller V, Spanos A, Frankfurter A (1996) Developmental expression of a neuron-specific $\beta$-tubulin in frog (Xenopus laevis): a marker for growing axons during the embryonic period. J Comp Neurol 364:219-230.

Morshead CM, Reynolds BA, Craig CG, McBurney MW, Staines WA, Morassutti D, Weiss S, Van der Kooy D (1994) Neural stem cells in the adult mammalian forebrain: a relatively quiescent subpopulation of subependymal cells. Neuron 13:1071-1082.

O'Rourke NA, Sullivan DP, Kaznowski CE, Jacobs AA, McConnell SK (1995) Tangential migration of neurons in the developing cerebral cortex. Development (Camb) 121:2165-2176.

Palmer TD, Ray J, Gage FH (1995) FGF-2 responsive neuronal progenitors reside in proliferative and quiescent regions of the adult rodent brain. Mol Cell Neurosci 6:474-486.

Paterson JA, Privat A, Ling EA, Leblond CP (1973) Investigation of glial cells in semithin sections. III. Transformation of subependymal cells into glial cells, as shown by radioautography after ${ }^{3} \mathrm{H}$-thymidine injection into the lateral ventricle of the brain of young rats. J Comp Neurol 149:83-102.

Peters E, Palay SL, Webster H de F (1991) The fine structure of the nervous system: neurons and their supporting cells. New York: Oxford UP.

Privat A (1974) A possible mechanism for the resorption of attachment plates in the growing rat brain. Brain Res 69:125-129.

Privat A, Leblond CP (1972) The subependymal layer and neighboring region in the brain of the young rat. J Comp Neurol 146:277-302.

Rakic P, Sidman RL (1969) Telencephalic origin of pulvinar neurons in the fetal human brain. Z Anat Entwicklungsgesch 129:53-82.

Reynolds B, Weiss S (1992) Generation of neurons and astrocytes from isolated cells of the adult mammalian central nervous system. Science 255:1707-1710.

Rhodin JAG (1974) Histology. New York: Oxford UP.

Richards LJ, Kilpatrick TJ, Bartlett PF (1992) De novo generation of neuronal cells from the adult mouse brain. Proc Natl Acad Sci USA 89:8591-8595

Rousselot P, Lois C, Alvarez-Buylla A (1995) Embryonic (PSA) N-CAM reveals chains of migrating neuroblasts between the lateral ventricle and the olfactory bulb of adult mice. J Comp Neurol 351:51-61.

Sancho-Tello M, Vallés S, Montoliu C, Renau-Piqueras J, Guerri C (1995) Developmental pattern of GFAP and vimentin gene expression in rat brain and in radial glial cultures. Glia 15:157-166.

Schiffer D, Giordana MT, Migheli A, Giaccone G, Pezzotta S, Mauro A (1986) Glial fibrillary acidic protein and vimentin in the experimental glial reaction of the rat brain. Brain Res 374:110-118.

Schwob JE, Farber NB, Gottlieb DI (1986) Neurons of the olfactory epithelium in adult rats contain vimentin. J Neurosci 6:208-217.

Smart I (1961) The subependymal layer of the mouse brain and its cell production as shown by radioautography after thymidine-H3 injection. J Comp Neurol 116:325-348.

Sturrock RR, Smart IHM (1980) A morphological study of the mouse subependymal layer from embryonic life to old age. J Anat 130:391-415.

Theodosis DT, Rougon G, Poulain DA (1991) Retention of embryonic features by an adult neuronal system capable of plasticity: polysialylated neural cell adhesion molecule in the hypothalamo-neurohypophysial system. Proc Natl Acad Sci USA 88:5494-5498.

Tohyama T, Lee VM-Y, Rorke LB, Marvin M, McKay RDG, Trojanowski JQ (1992) Nestin expression in embryonic human neuroepithelium and in human neuroepithelial tumor cells. Lab Invest 66:303-313.

Weiss S, Dunne C, Hewson J, Wohl C, Wheatley M, Peterson AC, Reynolds BA (1996a) Multipotent CNS stem cells are present in the adult mammalian spinal cord and ventricular neuroaxis. J Neurosci 16:7599-7609.

Weiss S, Reynolds BA, Vescovi AL, Morshead C, Craig CG, Van der Kooy D (1996b) Is there a neural stem cell in the mammalian forebrain? Trends Neurosci 19:387-393. 